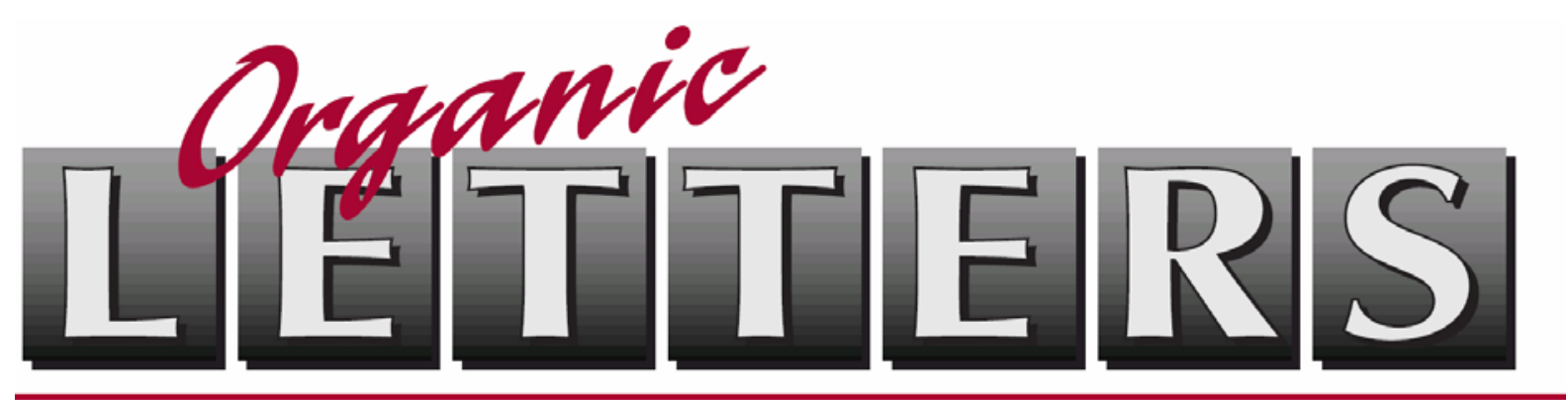

\title{
Silver(I) Mediated Folding of a Molecular Basket
}

Zhiqing Yan, Shijing Xia, Matthew Gardilik, Wanji Seo, Veselin Maslak, Judith Gallucci, Christopher M. Hadad, and Jovica D. Badjić*

badjic@chemistry.ohio-state.edu

\section{Supporting Information}


General: All chemicals were purchased from commercial sources, and used as received unless stated otherwise. All solvents were dried prior to use according to standard literature protocols. Chromatography purifications were performed using silica gel 60 (Sorbent technologies 40-75 $\mu \mathrm{m}, 200 \times 400 \mathrm{mesh}$ ). Thin-layer chromatography (TLC) was performed on silica-gel plate w/UV254 $(200 \mu \mathrm{m})$. Chromatograms were visualized by UV-light, and if need by staining using $20 \%$ phosphomolybdic acid in ethanol. ${ }^{1} \mathrm{H}$ and ${ }^{13} \mathrm{C}$ NMR spectra were recorded, at $500 \mathrm{MHz}$ and $125 \mathrm{MHz}$, on a Bruker DRX-500 spectrometer. They were referenced using the solvent residual signal as internal standard. Samples were prepared using $\mathrm{CDCl}_{3}$ and $\mathrm{CD}_{3} \mathrm{OD}$ purchased from Cambridge Isotope Laboratories. The chemical shift values are expressed as $\delta$ values and the coupling constants values $(J)$ are in Hertz $(\mathrm{Hz})$. The following abbreviations were used for signal multiplicities: s, singlet; d, doublet; t, triplet; m, multiplet; and br, broad. MALDI-TOF mass spectra were measured on a Bruker Reflex III MALDI-TOF spectrometer and 2,5-Dihydroxybenzoic acid as matrix. Microcalorimetric experiments were performed using an isothermal titration calorimeter (VP-ITC, MicroCal, Northampton, MA). The heat of reaction was corrected for the heat of dilution of the guest solution, determined in separate experiments. All solutions were degassed prior to the titration experiment according to the method provided by MicroCal. Computer simulations (curve fitting) were performed using the ORIGIN 7.0 software, adapted for ITC data analysis. The "Single Set of Identical Sites" model was applied in all cases.

Synthesis. Compound 7 was synthesized following the protocol described in ref. 6.

Preparation of compound 4: To a solution of trisanhydride $1(2.5 \mathrm{mg}, 0.004 \mathrm{mmol})$ in toluene $(1.0 \mathrm{ml})$, was added a solution of 3-(aminomethyl)pyridine $2(2.6 \mathrm{mg}, 0.024$ $\mathrm{mmol})$ in toluene $(0.5 \mathrm{ml})$. Then neat pyridine $(150.0 \mu \mathrm{l})$ was added, before the solution was heated to reflux for $12 \mathrm{~h}$. The reaction mixture was then cooled to room temperature, evaporated in vauo, and the residue purified by column chromatography $\left(\mathrm{SiO}_{2}\right.$, benzene/acetone, 3:1) to yield white solid product (3.6 mg, $87 \%)$. ${ }^{1} \mathrm{H}$ NMR (500 $\mathrm{MHz}$, $\left.\mathrm{CDCl}_{3}, 27^{\circ} \mathrm{C}\right): \delta=8.25(\mathrm{~s}, 3 \mathrm{H}), 8.16(\mathrm{~s}, 3 \mathrm{H}), 7.46(\mathrm{~d}, 3 \mathrm{H}), 7.30(\mathrm{~s}, 6 \mathrm{H}), 7.03(\mathrm{dd}, 3 \mathrm{H})$, $4.44(\mathrm{~s}, 6 \mathrm{H}), 4.32(\mathrm{~s}, 6 \mathrm{H})$, and $2.34(\mathrm{~s}, 6 \mathrm{H}) \mathrm{ppm} ;{ }^{13} \mathrm{C} \mathrm{NMR}\left(100 \mathrm{MHz}, \mathrm{CDCl}_{3}, 27^{\circ} \mathrm{C}\right): \delta=$ $167.6(\mathrm{C}=\mathrm{O}), 156.8(\mathrm{CH}), 137.8(\mathrm{CH}), 136.3(\mathrm{C}), 129.0(\mathrm{CH}), 128.2(\mathrm{CH}), 125.3(\mathrm{CH})$, $123.4(\mathrm{C}), 122.7(\mathrm{C}), 118.5(\mathrm{C}), 68.2\left(\mathrm{CH}_{2}\right), 49.3(\mathrm{CH})$, and $42.7\left(\mathrm{CH}_{2}\right) \mathrm{ppm}$. MALDI-TOF $\mathrm{m} / \mathrm{z}$ calcd for $\mathrm{C}_{57} \mathrm{H}_{36} \mathrm{~N}_{6} \mathrm{O}_{6} \mathrm{Na}$ : $923.260[\mathrm{M}+\mathrm{Na}]^{+}$, found: 923.331 . 


\section{D ${ }^{1} \mathrm{H}$ NMR Characterization of 4}

Figure S1. The 2D COSY NMR spectrum (500 MHz, $\left.\mathrm{CDCl}_{3} / \mathrm{CD}_{3} \mathrm{OD}=1: 1,1.6 \mathrm{mM}, 300 \mathrm{~K}\right)$ of 4.

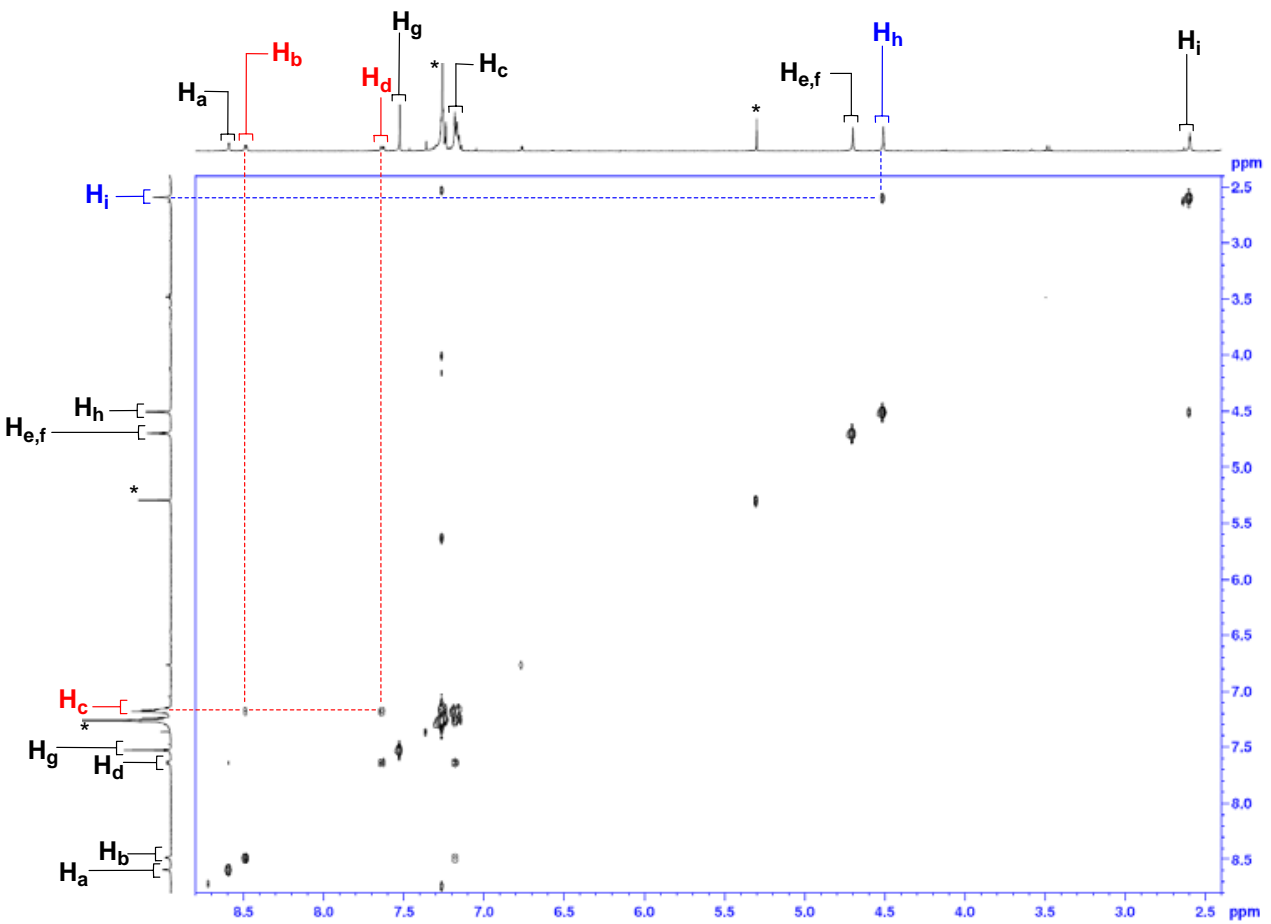

Figure S2. The 2D NOESY NMR spectrum $\left(500 \mathrm{MHz}, \mathrm{CDCl}_{3} / \mathrm{CD}_{3} \mathrm{OD}=1: 1,1.6 \mathrm{mM}, 300 \mathrm{~K}\right.$ ) of 4 .

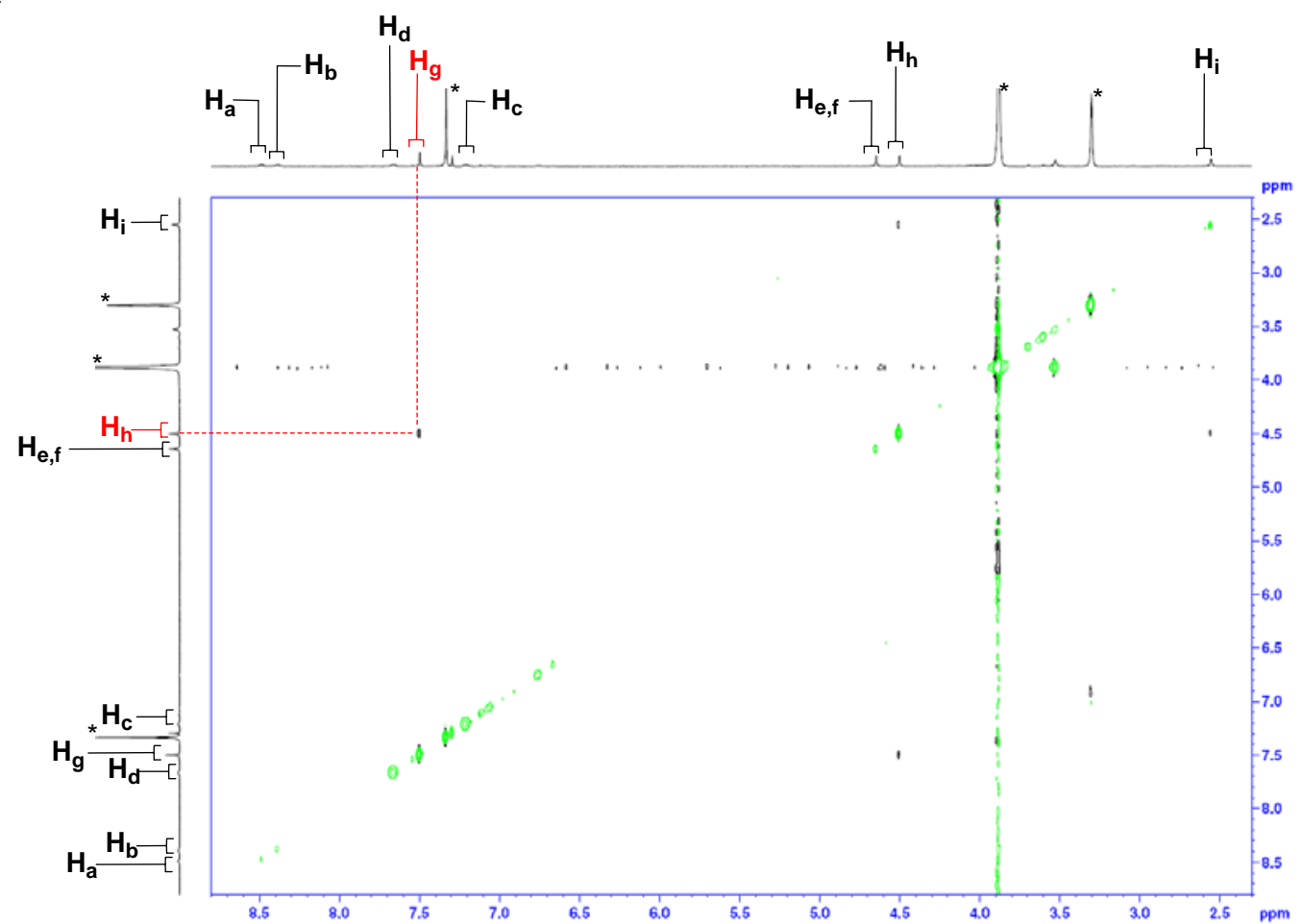




\section{Titration of 5 with $\mathrm{Ag}(\mathrm{I})$}

Figure S3. The ${ }^{1} \mathrm{H}$ NMR spectra of $2.67 \mathrm{mM}$ solution of $5\left(500 \mathrm{MHz}, \mathrm{CDCl}_{3} / \mathrm{CD}_{3} \mathrm{OD}=1: 1,300\right.$ $\mathrm{K})$ titrated with $29.0 \mathrm{mM}$ standard solution of $\mathrm{AgOTf}\left(\mathrm{CDCl}_{3} / \mathrm{CD}_{3} \mathrm{OD}=1: 1\right)$.

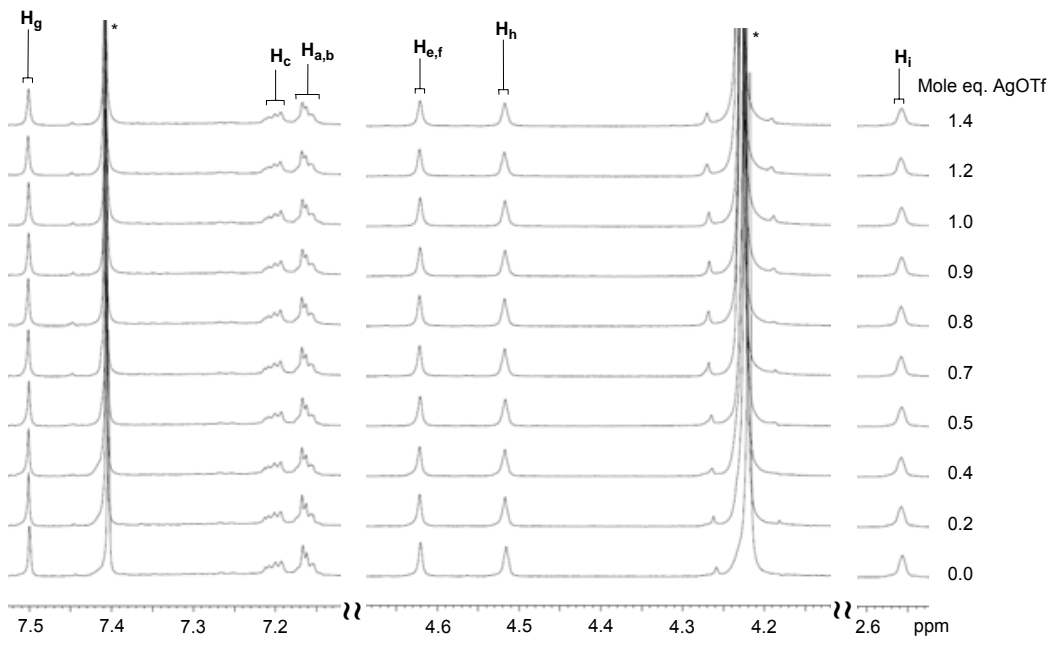

\section{${ }^{1} \mathrm{H}$ NMR Binding Constant for the Formation of 6}

Figure S4. The non-linear curve fitting (1:1 equilibrium model $)^{1}$ of the ${ }^{1} \mathrm{H}$ NMR chemical shifts of the $\mathrm{H}_{\mathrm{a}}, \mathrm{H}_{\mathrm{d}}$ and $\mathrm{H}_{\mathrm{c}}$ resonances in 4 , obtained by incremental addition of $124.0 \mathrm{mM}$ standard solution of $\mathrm{AgOTf}\left(\mathrm{CDCl}_{3} / \mathrm{CD}_{3} \mathrm{OD}=1: 1\right)$ to $5.40 \mathrm{mM}$ solution of $4\left(500 \mathrm{MHz}, \mathrm{CDCl}_{3} / \mathrm{CD}_{3} \mathrm{OD}=\right.$ $1: 1,300 \mathrm{~K})$.

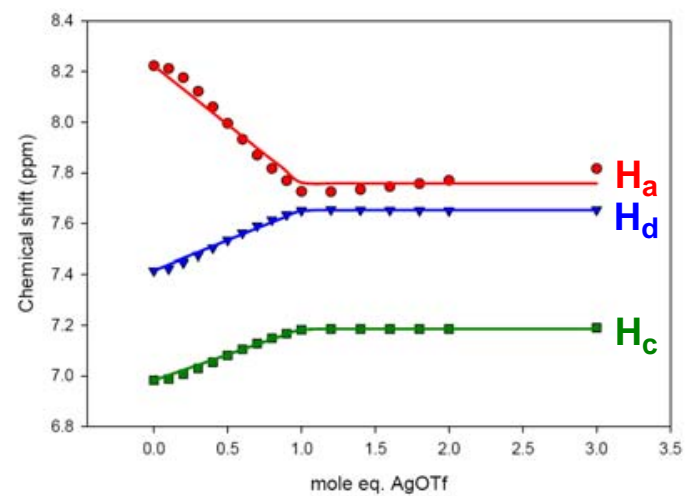

\begin{tabular}{lllll}
\hline Proton & $\delta(\mathrm{ppm})$ & $\delta($ saturated with $\mathrm{Ag})(\mathrm{ppm})$ & $\Delta \delta(\mathrm{ppm})$ & $K_{a}\left(\mathrm{M}^{-1}\right)$ \\
\hline $\mathrm{H}_{\mathrm{a}}$ & 8.22 & 7.76 & 0.46 & $3.3 \times 10^{6}$ \\
$\mathrm{H}_{\mathrm{d}}$ & 7.42 & 7.65 & -0.23 & $4.5 \times 10^{5}$ \\
$\mathrm{H}_{\mathrm{c}}$ & 6.98 & 7.19 & -0.44 & $1.1 \times 10^{6}$ \\
\hline
\end{tabular}

The fitting equation: ${ }^{\prime}$

$$
\begin{gathered}
\delta_{o b s}=\delta_{\mathbf{4}}+\frac{\Delta \delta}{2 \times[\mathbf{4}]} \times\left[[\mathbf{4}]+[\mathrm{Ag}]+\frac{1}{K_{a}}-\sqrt{\left(\frac{1}{K_{a}}+[\mathbf{4}]+[\mathrm{Ag}]\right)^{2}-(4 \times[\mathbf{4}] \times[\mathrm{Ag}])}\right] \\
K_{a v g}=\frac{K_{H_{a}}+K_{H_{c}}+K_{H_{d}}}{3}=(1.6 \pm 1.1) \times 10^{6} \mathrm{M}^{-1}
\end{gathered}
$$


Mass Spectrometry Characterization of 6

Figure S5. Low-Resolution MALDI-TOF mass spectrum of 6, with a major peak at $\mathrm{m} / \mathrm{z} 1007.306$ corresponding to the $[6-\mathrm{OTf}]^{+}$ion.

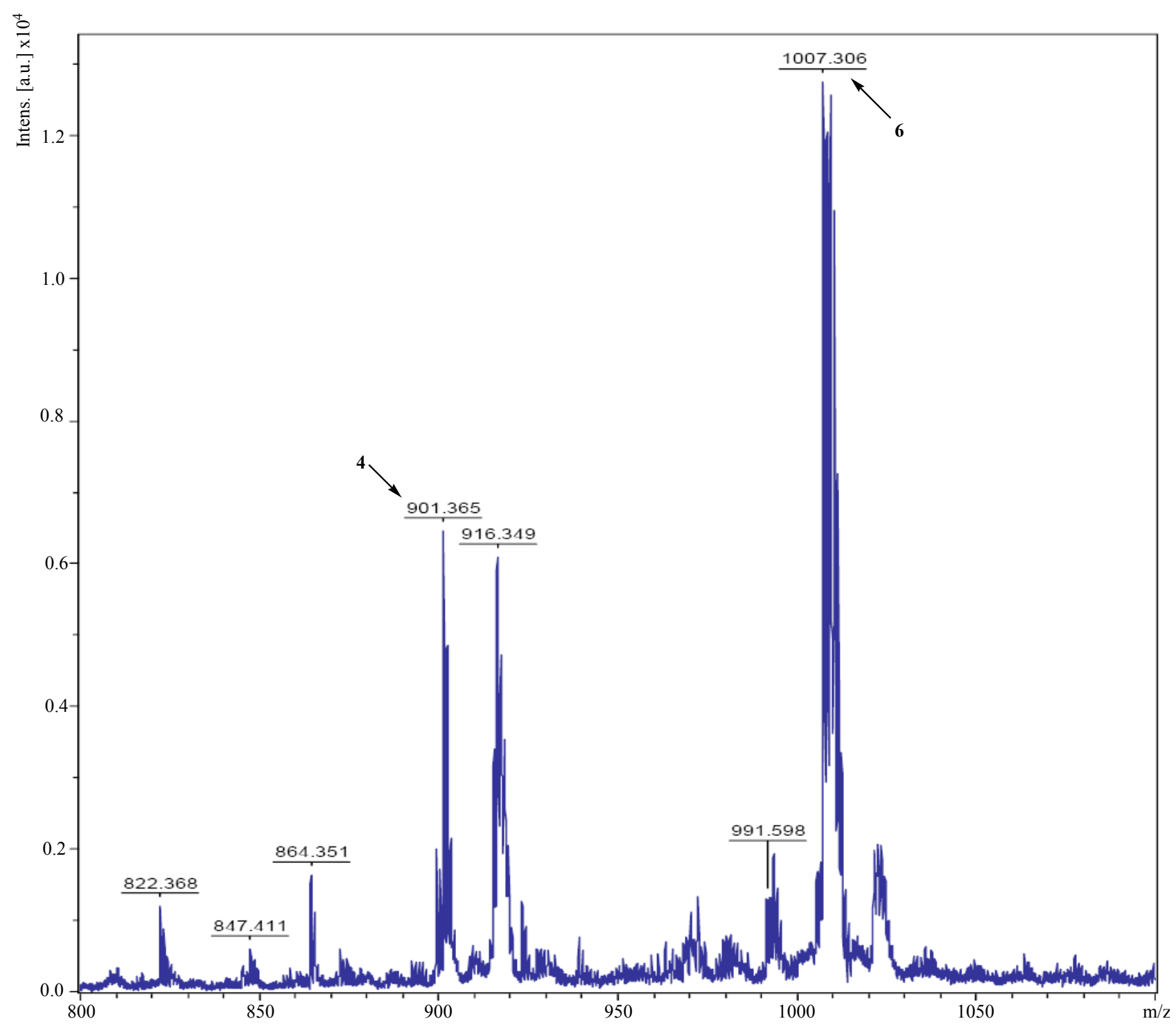




\section{Diffusion Coefficients Measurements of 4 and 6 by ${ }^{1} \mathrm{H}$ NMR}

Figure S6. The 2D NMR DOSY spectrum of $4\left(500 \mathrm{MHz}, \mathrm{CDCl}_{3} / \mathrm{CD}_{3} \mathrm{OD}=1: 1,1.6 \mathrm{mM}, 300 \pm\right.$ $1 \mathrm{~K})$.

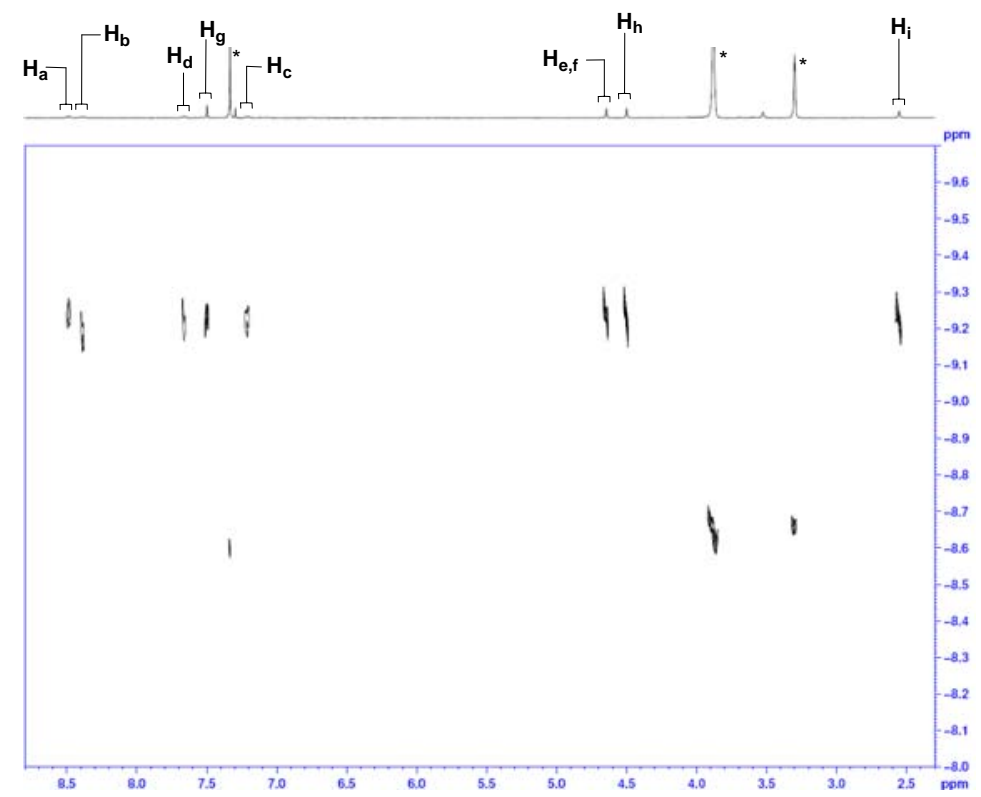

Note: The 2D NMR DOSY experiment was repeated three times. The mean average diffusion coefficient ${ }^{2}$ of $5.56 \pm 0.13 \times 10^{-10} \mathrm{~m}^{2} / \mathrm{s}$ is reported; On the basis of that the corresponding hydrodynamic radius was calculated ${ }^{2}$ to be $7.37 \pm 0.18 \AA$.

Figure S7. The 2D NMR DOSY spectrum of $6\left(500 \mathrm{MHz}, \mathrm{CDCl}_{3} / \mathrm{CD}_{3} \mathrm{OD}=1: 1,1.6 \mathrm{mM}, 300 \pm\right.$ $1 \mathrm{~K})$.

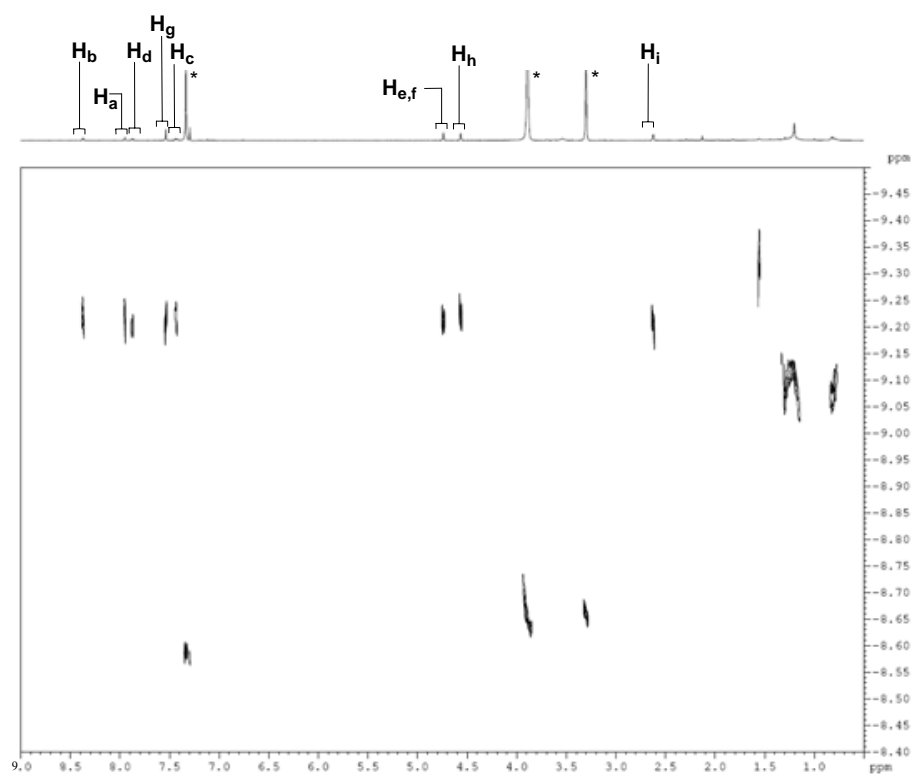

Note: The 2D NMR DOSY experiment was repeated three times. The mean average diffusion coefficient ${ }^{2}$ of $\left.6.09 \pm 0.06\right) \times 10^{-10} \mathrm{~m}^{2} / \mathrm{s}$ is reported. On the basis of that the corresponding hydrodynamic radius was calculated ${ }^{2}$ to be $6.73 \pm 0.07 \AA$. 


\section{NOESY and VT NMR Spectra of 6}

Figure S8. The 2D NMR NOESY spectrum of $6\left(500 \mathrm{MHz}, \mathrm{CDCl}_{3} / \mathrm{CD}_{3} \mathrm{OD}=1: 1,1.36 \mathrm{mM}, 300\right.$ $\mathrm{K})$. Selected region of the NOESY spectrum (bottom part) reveals the $\mathbf{H}_{\mathrm{a}} / \mathbf{H}_{\mathrm{b}}$ correlation through space.

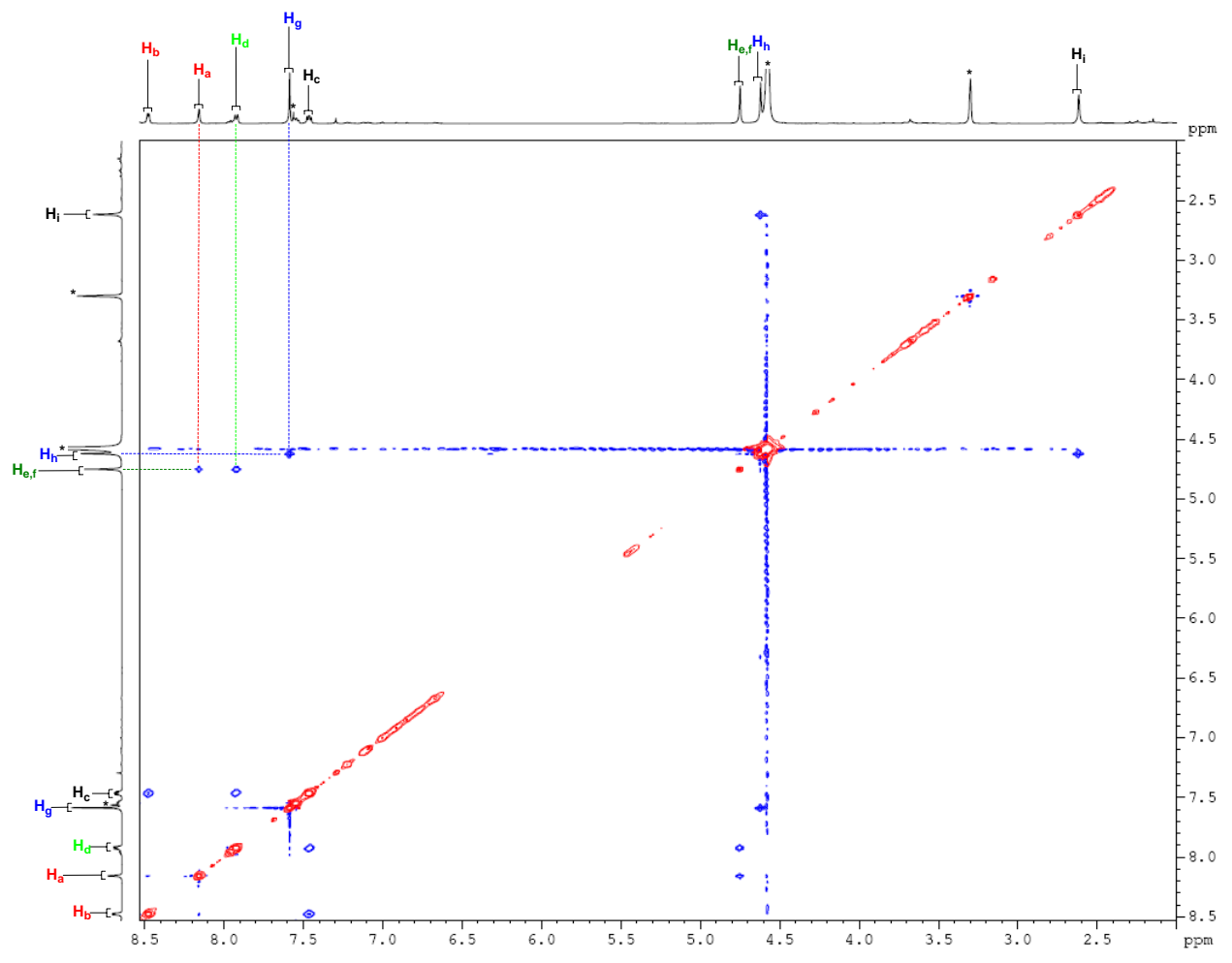

Figure S9. Variable temperature ${ }^{1} \mathrm{H}$ NMR spectra of $8.2 \mathrm{mM}$ solution of $6(500 \mathrm{MHz}$, $\left.\mathrm{CD}_{2} \mathrm{Cl}_{2} / \mathrm{CD}_{3} \mathrm{OD}=9: 1\right)$.

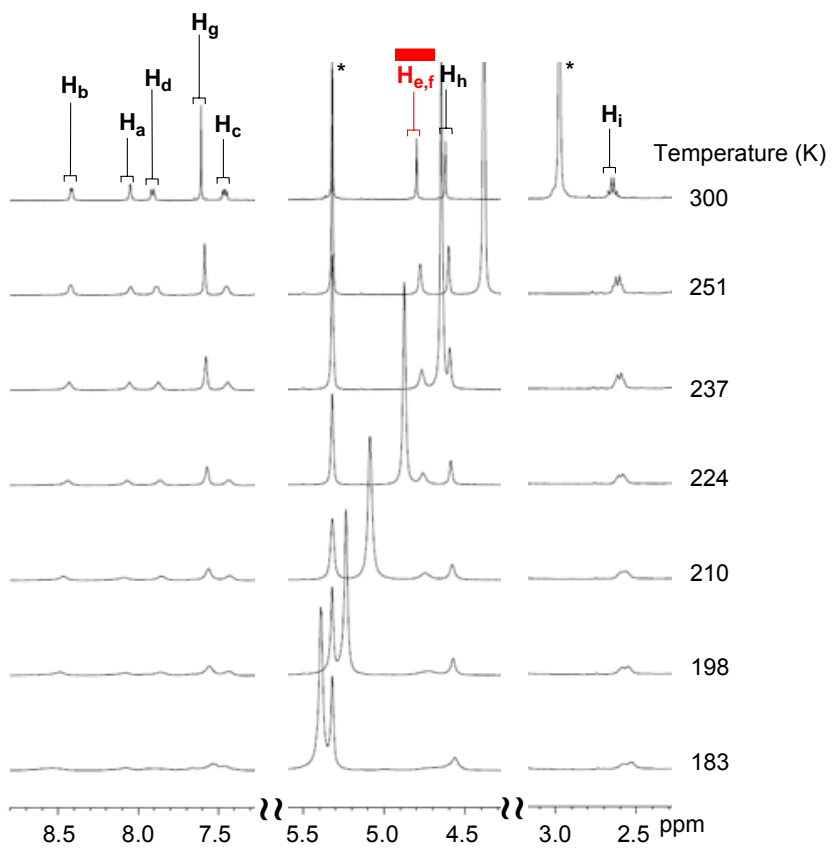


NMR Studies of the Binding of Imidazole 8 to $\mathbf{6}$

Figure S10. The ${ }^{1} \mathrm{H}$ NMR spectra of $9.0 \mathrm{mM}$ solution of $4\left(500 \mathrm{MHz}, \mathrm{CDCl}_{3} / \mathrm{CD}_{3} \mathrm{OD}=1: 1\right.$, $300 \mathrm{~K})$ containing 0.7 molar eqivalents of $\operatorname{AgOTf}(6.3 \mathrm{mM})$ and titrated with $112.0 \mathrm{mM}$ standard solution of imidazole $\left(\mathrm{CDCl}_{3} / \mathrm{CD}_{3} \mathrm{OD}=1: 1\right)$.

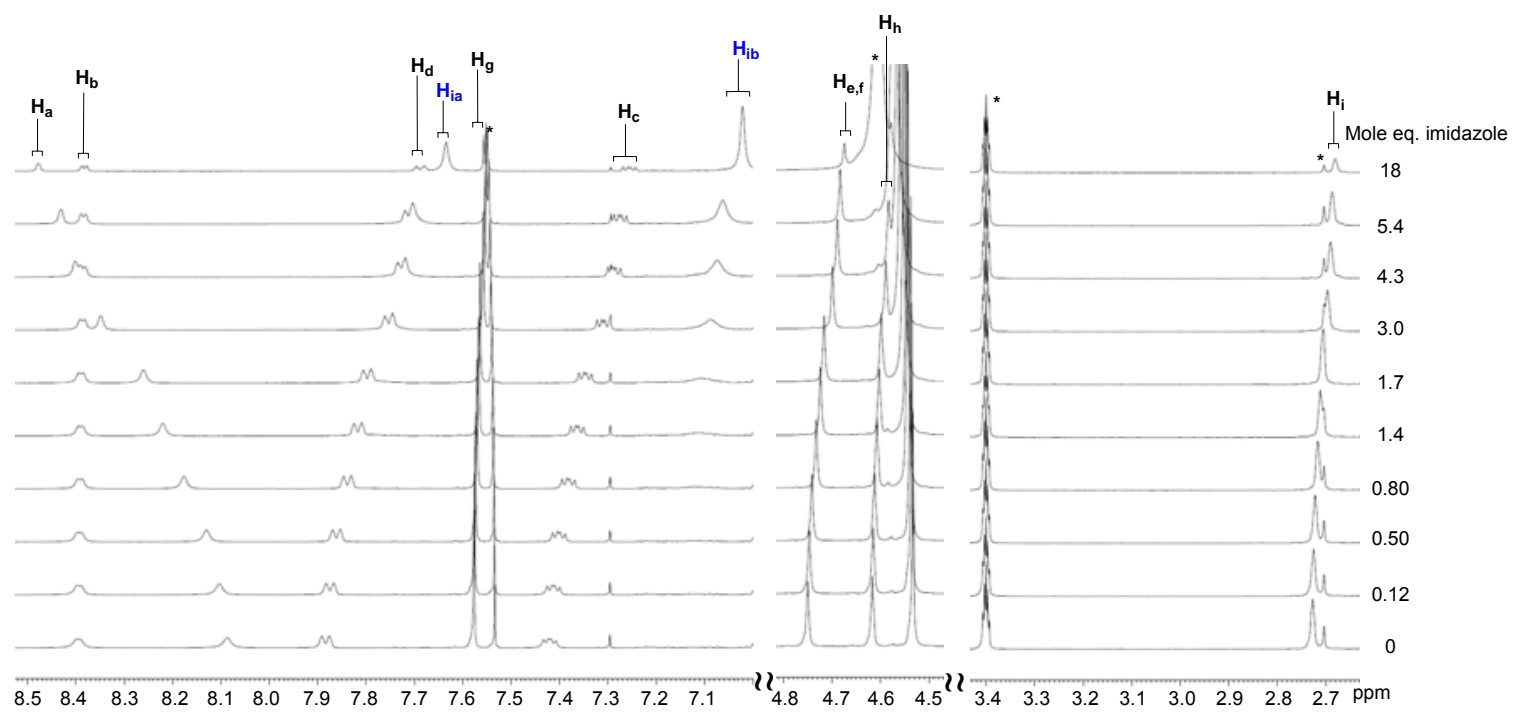

Figure S11. The 2D NMR DOSY spectrum of imidazole $\left(500 \mathrm{MHz}, \mathrm{CDCl}_{3} / \mathrm{CD}_{3} \mathrm{OD}=1: 1,112\right.$ $\mathrm{mM}, 300 \pm 1 \mathrm{~K})$.
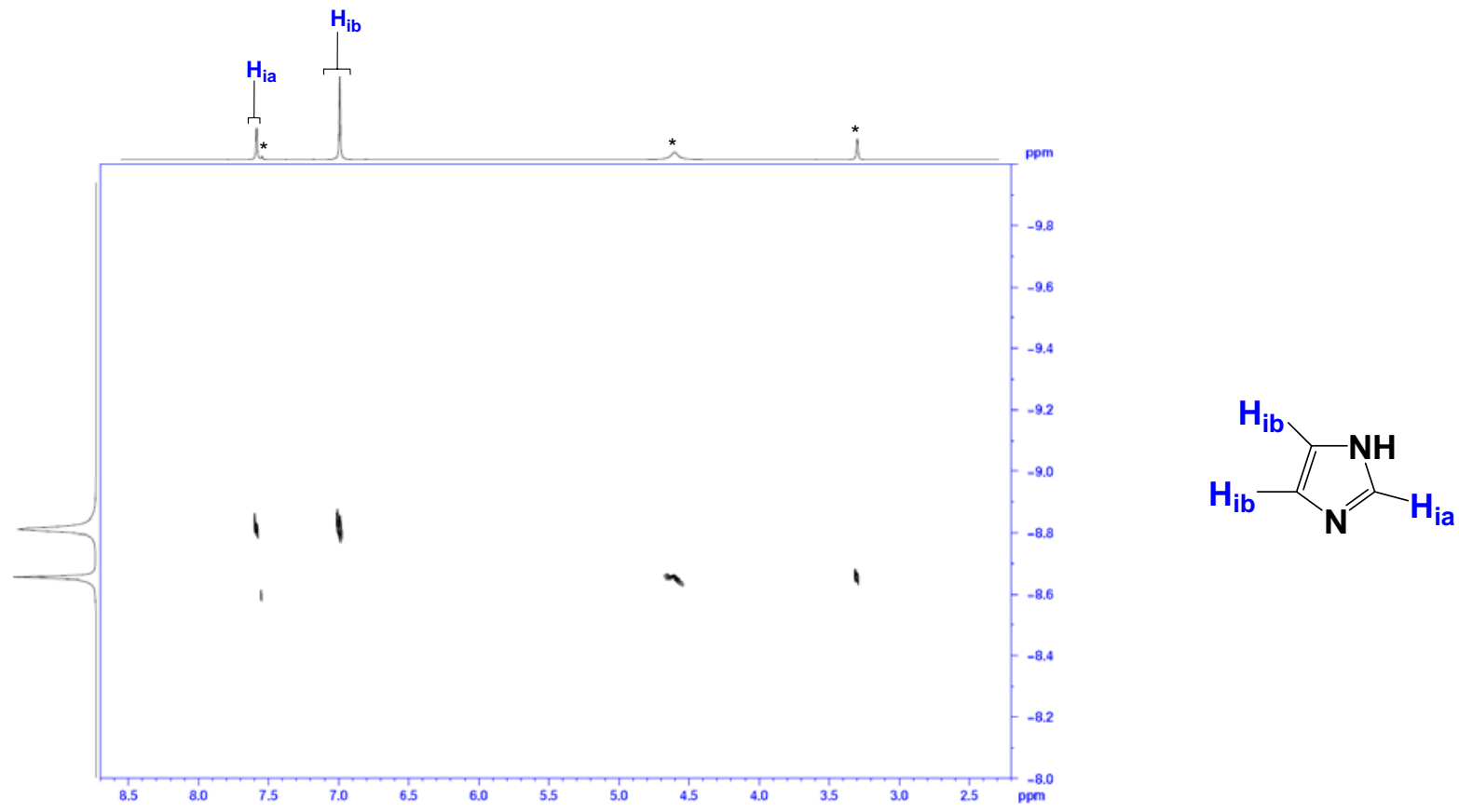
Figure S12. The 2D NMR DOSY spectrum of an equimolar mixture of $\mathbf{6}$ and imidazole (500 $\left.\mathrm{MHz}, \mathrm{CDCl}_{3} / \mathrm{CD}_{3} \mathrm{OD}=1: 1,2.2 \mathrm{mM}, 300 \pm 1 \mathrm{~K}\right)$.

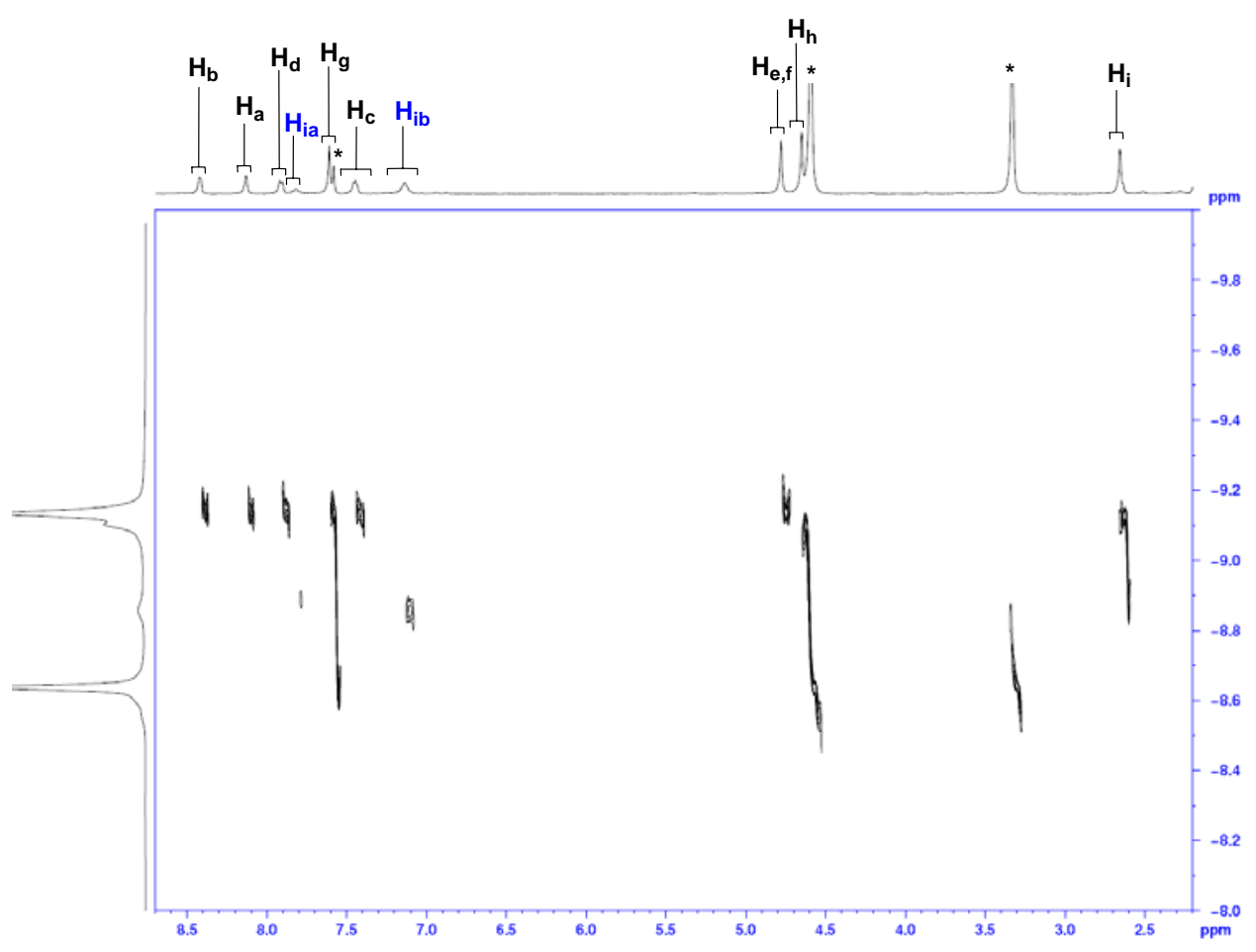

Figure S13. The 2D NMR DOSY spectrum of $100.0 \mathrm{mM}$ solution of imidazole containing 50.0 $\mathrm{mM} \operatorname{AgOTf}\left(500 \mathrm{MHz}, \mathrm{CDCl}_{3} / \mathrm{CD}_{3} \mathrm{OD}=1: 1,300 \pm 1 \mathrm{~K}\right)$.

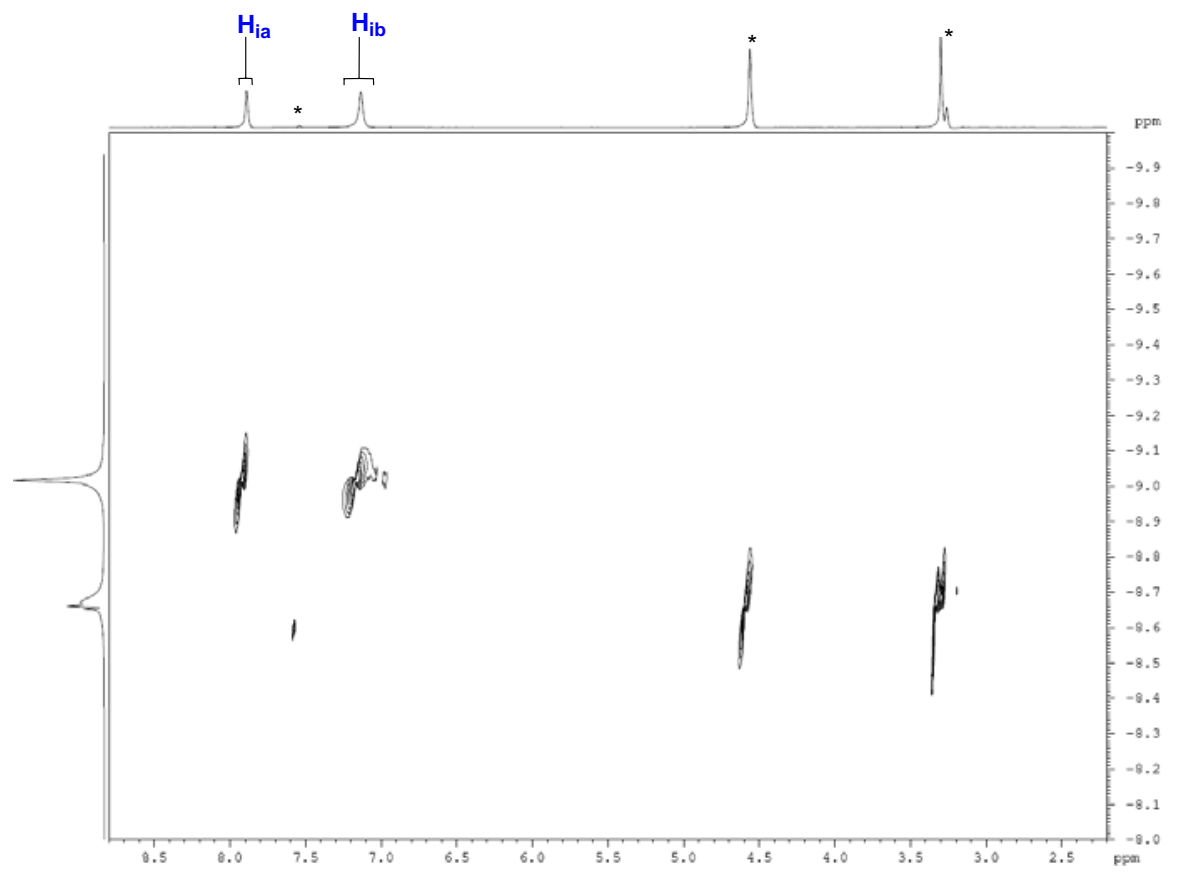


NMR Studies of the Binding of Azetidine 10 to $\mathbf{6}$

Figure S14. The ${ }^{1} \mathrm{H}$ NMR spectra of solution of $6\left(500 \mathrm{MHz}, \mathrm{CDCl}_{3} / \mathrm{CD}_{3} \mathrm{OD}=1: 1,2.2 \mathrm{mM}\right.$, $300 \mathrm{~K})$ titrated with $143.0 \mathrm{mM}$ standard solution of azetidine $\left(\mathrm{CDCl}_{3} / \mathrm{CD}_{3} \mathrm{OD}=1: 1\right)$.
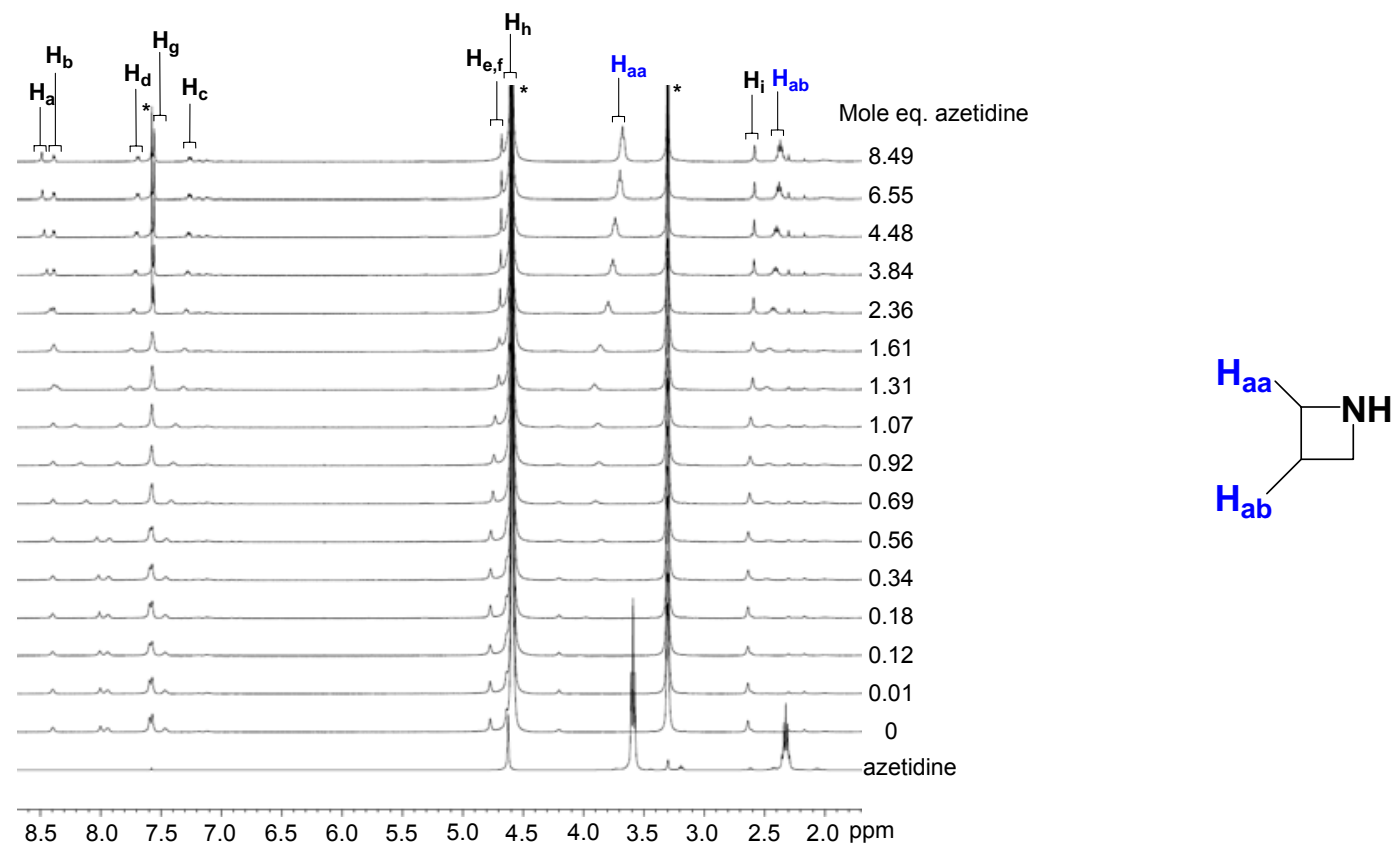

NMR Studies of the Binding of Aziridine 9 to 6

Figure S15. The ${ }^{1} \mathrm{H}$ NMR spectra of $2.20 \mathrm{mM}$ solution of $6\left(500 \mathrm{MHz}, \mathrm{CDCl}_{3} / \mathrm{CD}_{3} \mathrm{OD}=1: 1\right.$, $300 \mathrm{~K})$ titrated with $70.0 \mathrm{mM}$ standard solution of aziridine $\left(\mathrm{CDCl}_{3} / \mathrm{CD}_{3} \mathrm{OD}=1: 1\right)$.

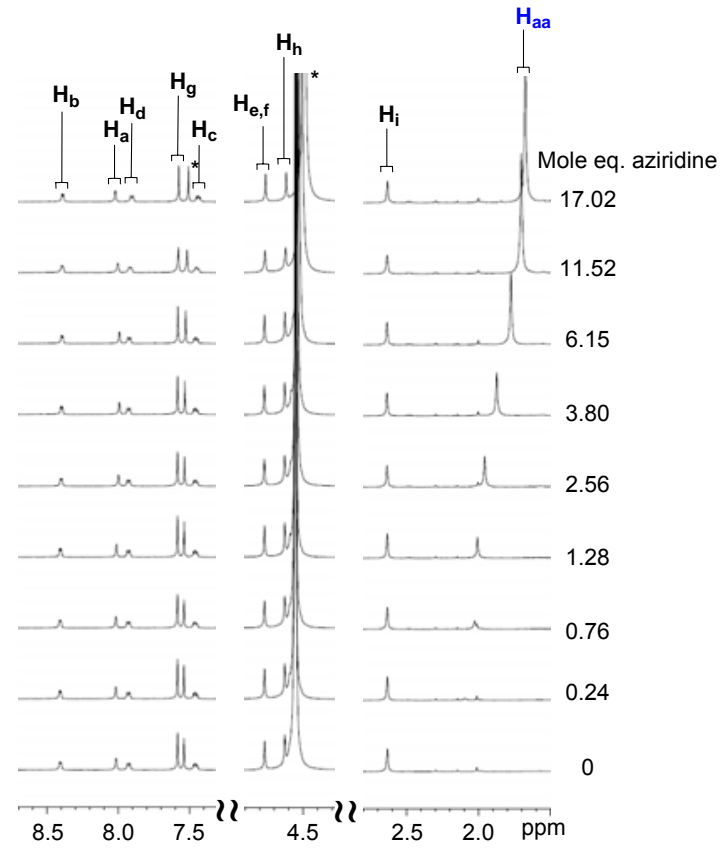




\section{NMR Studies of the Binding of Thiirane $\mathbf{1 1}$ to $\mathbf{6}$}

Figure S16. The ${ }^{1} \mathrm{H}$ NMR spectra of $2.2 \mathrm{mM}$ solution of $6\left(500 \mathrm{MHz}, \mathrm{CDCl}_{3} / \mathrm{CD}_{3} \mathrm{OD}=1: 1\right.$, $300 \mathrm{~K})$ titrated with $76.0 \mathrm{mM}$ standard solution of thiirane $\left(\mathrm{CDCl}_{3} / \mathrm{CD}_{3} \mathrm{OD}=1: 1\right)$.
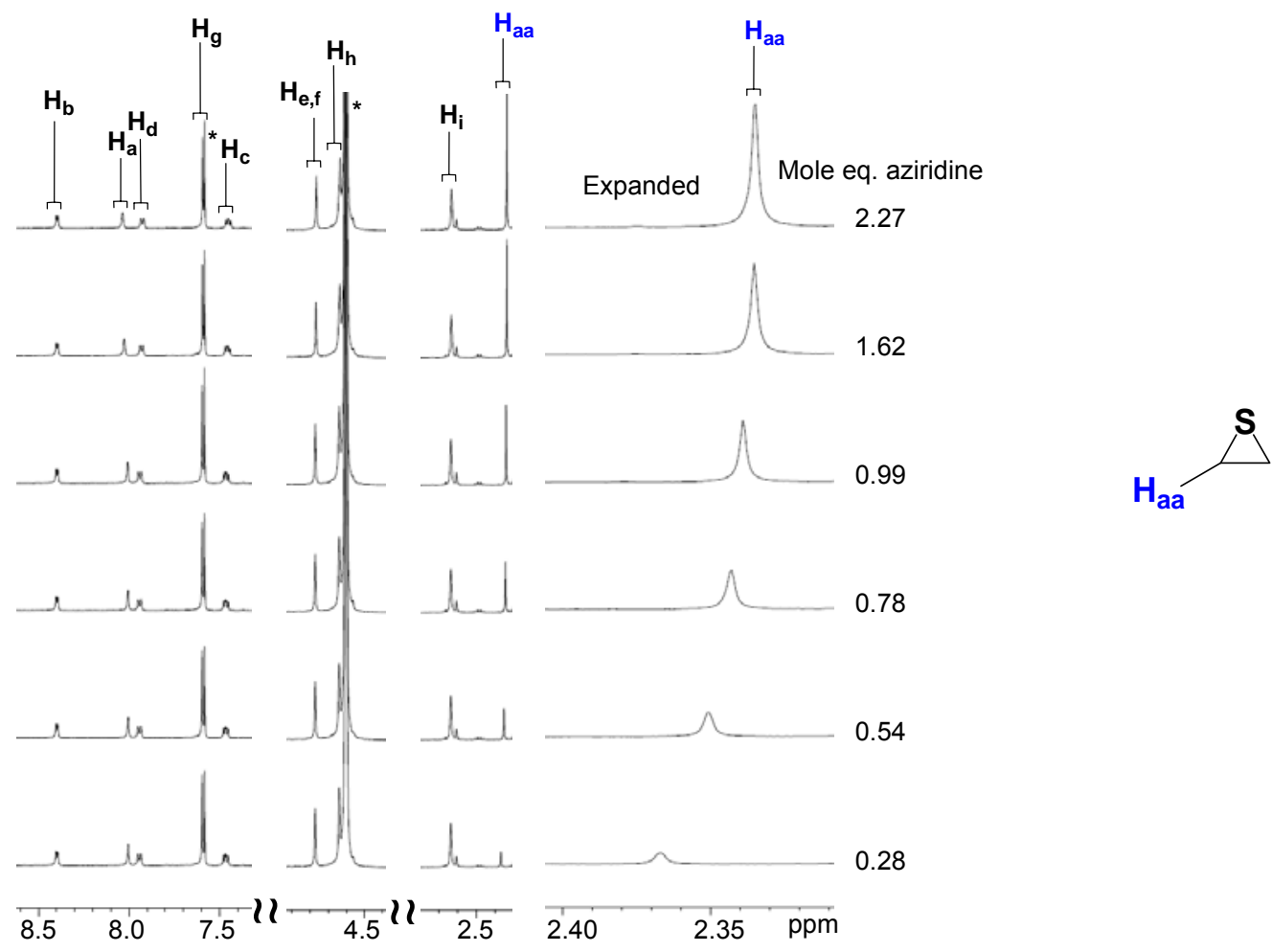

${ }^{1} \mathrm{H}$ NMR spectrum of the Mixture of Ethylene $\mathbf{1 2}$ and $\mathbf{6}$

Figure S17. The ${ }^{1} \mathrm{H}$ NMR spectra of $2.20 \mathrm{mM}$ solution of $6\left(500 \mathrm{MHz}, \mathrm{CDCl}_{3} / \mathrm{CD}_{3} \mathrm{OD}=\right.$ $1: 1,300 \mathrm{~K})$ bubbled with ethylene gas for 1 minute.

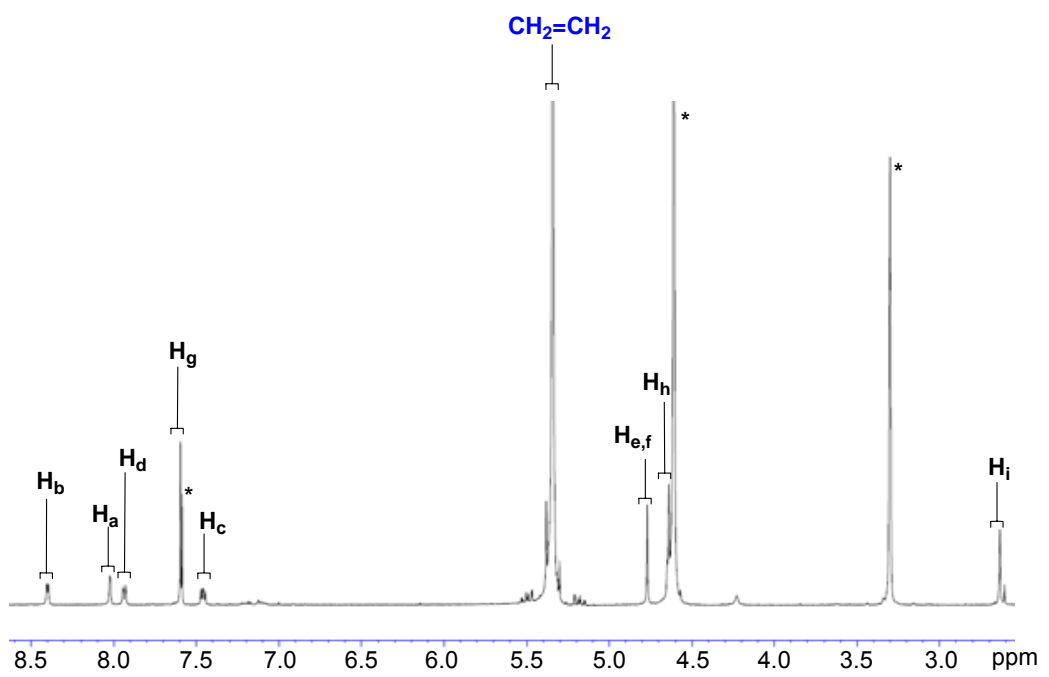




\section{THEORETICAL CALCULATIONS}

All calculations for optimization of conformations of compound $\mathbf{6}$ were carried out by using the Resolution of Identity Density Functional Theory (RI-DFT) method. ${ }^{3,4}$ The Generalized Gradient Approximation (GGA) BP86 functional $1^{5,6}$ was adopted. The RI-DFT method is implemented in the program package TURBOMOLE. ${ }^{711}$ The def-SV(P) basis sets were used for the lighter elements, while for silver relativistic effective core potential (ECP) and the triple-zeta plus polarization def-TZVP basis set were used. ${ }^{12}$

All conformations of compound $\mathbf{6}$ were calculated with $C_{3}$ symmetry. The relaxed potential energy surface scan along $\mathrm{N}-\mathrm{C}-\mathrm{C}-\mathrm{C}$ dihedral angle was performed to study the conformational interconversion of compound $\mathbf{6}$, starting from the optimized geometry whose N-C-C-C dihedral angle is $-58.2^{\circ}$. (Table S1, Figure S18)

Table S1. Calculated energies for relaxed potential energy scan along dihedral angle N-C-C-C of 6.

\begin{tabular}{cccc}
\hline Conformation \# & $\mathrm{N}-\mathrm{C}-\mathrm{C}-\mathrm{C}\left(^{\circ}\right)$ & Potential energy (hartree) & Relative energy $(\mathrm{kcal} / \mathrm{mol})$ \\
\hline 1 & -58.2 & -3118.648231 & 0.04 \\
2 & -28.2 & -3118.645476 & 1.50 \\
3 & 1.7 & -3118.643147 & 2.72 \\
4 & 31.7 & -3118.645786 & 1.33 \\
5 & 61.8 & -3118.648311 & 0.00 \\
6 & 91.8 & -3118.642748 & 2.93 \\
7 & 121.8 & -3118.624185 & 12.73 \\
8 & 151.8 & -3118.594974 & 28.14 \\
9 & 181.8 & -3118.56351 & 44.73 \\
10 & 211.8 & -3118.545416 & 54.28 \\
11 & 241.8 & -3118.570002 & 41.31 \\
12 & 271.9 & -3118.644181 & 2.18 \\
1 & 301.8 & -3118.648231 & 0.04 \\
\hline
\end{tabular}

Figure S18. Calculate Energy profile of $\mathbf{6}$ for relaxed potential energy scan along dihedral angle N-C-C-C

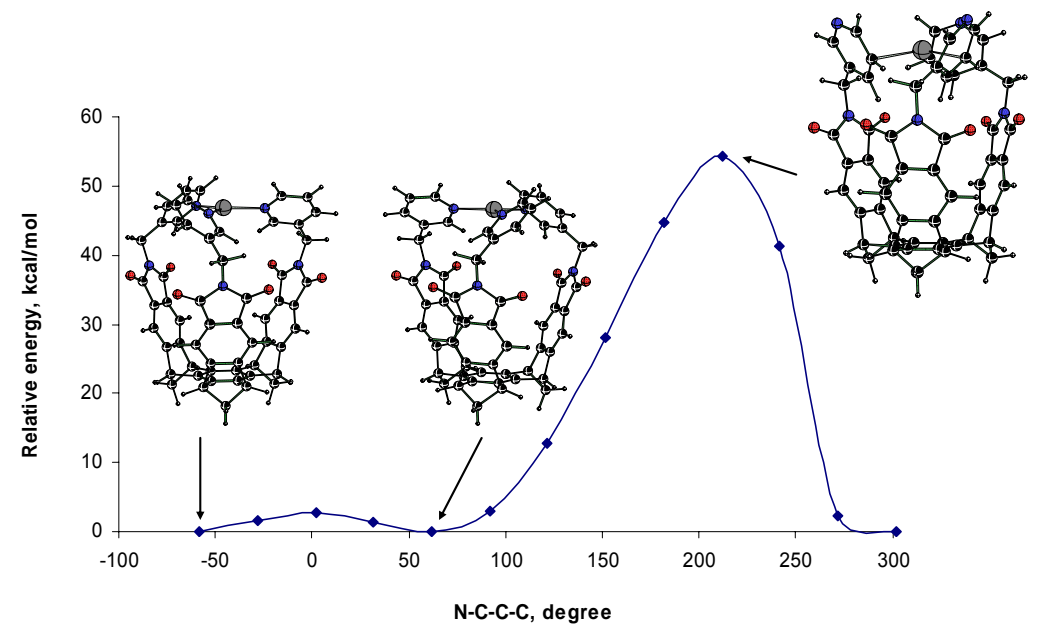


Considering that the size of equatorial portal in $\mathbf{6}$ is very similar to that of $\mathbf{4}$ (Figure S19), the compound 4 was used as a model to estimate the activation energies for the guest escape. All calculations were performed by semi-empirical (PM3) method using Gaussian 03 software. ${ }^{13} \mathrm{~A}$ reaction coordinate, $\chi$, was defined as a path by which a guest is forced the through the equatorial portal. Based on the method provided by Houk and coworkers (reference 19 in the article), and as illustrated by the dotted lines in Figure S20, a ghost atom was placed at $15 \AA$ away from the two hydrogens residing on the neighbouring pyridines of the host $\mathbf{4}$, and $14 \AA$ away from the two oxygen atoms and two hydrogen atoms of 4 . The distance between carbon $\left(\mathrm{CHCl}_{3}\right)$, oxygen $\left(\mathrm{CH}_{3} \mathrm{OH}\right)$ and the ghost atom was taken as the reaction coordinate. By gradually decreasing the distance between the guest molecule and the defined ghost atom, the activation energy for the guest escape was estimated by energy minimizations for each step (Figure S21).

Figure S19. Geometrical comparison between compounds 4 and 6.

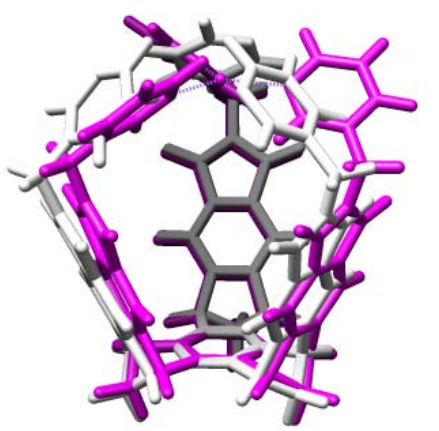

Side view

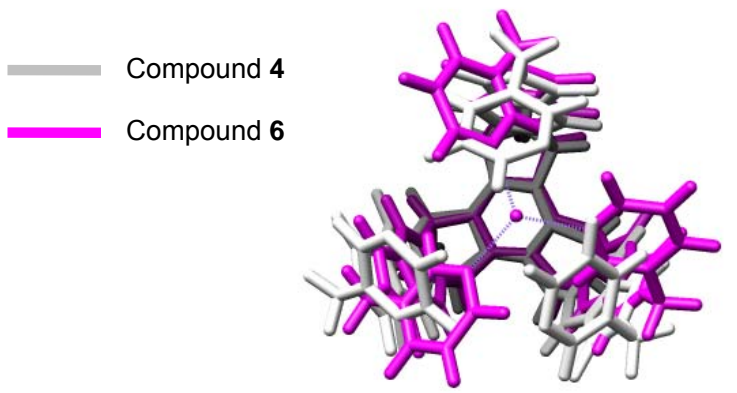

Top view

Figure S20. Definition of reaction coordinate, $\chi$, for the reaction path calculations of $\mathrm{CHCl}_{3}$ (upper part) and $\mathrm{CH}_{3} \mathrm{OH}$ (bottom part).

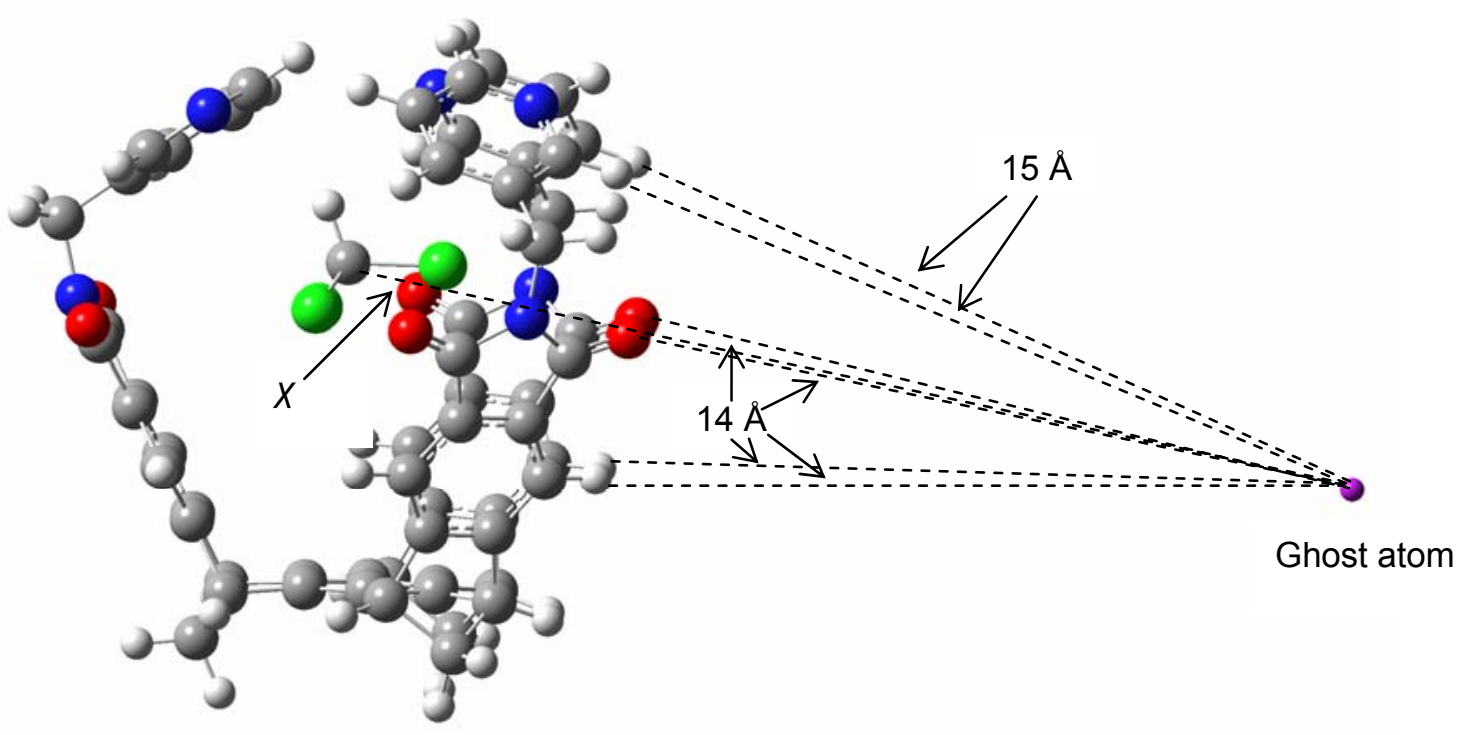




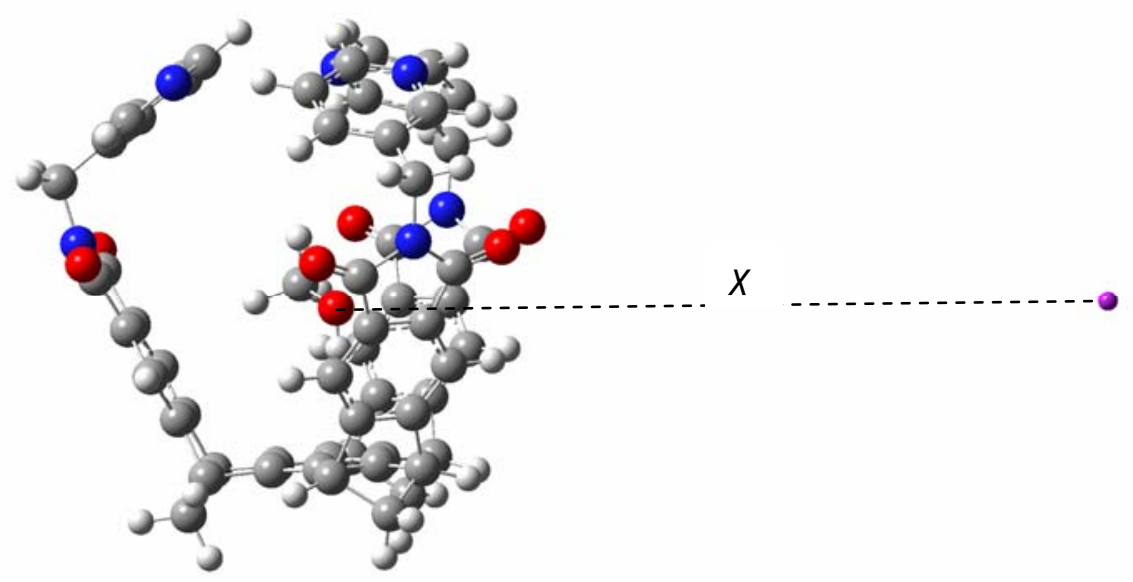

Figure S21. Calculated energy profile for the decomplexation of (a) $\mathrm{CHCl}_{3}$ and (b) $\mathrm{CH}_{3} \mathrm{OH}$ from 4.

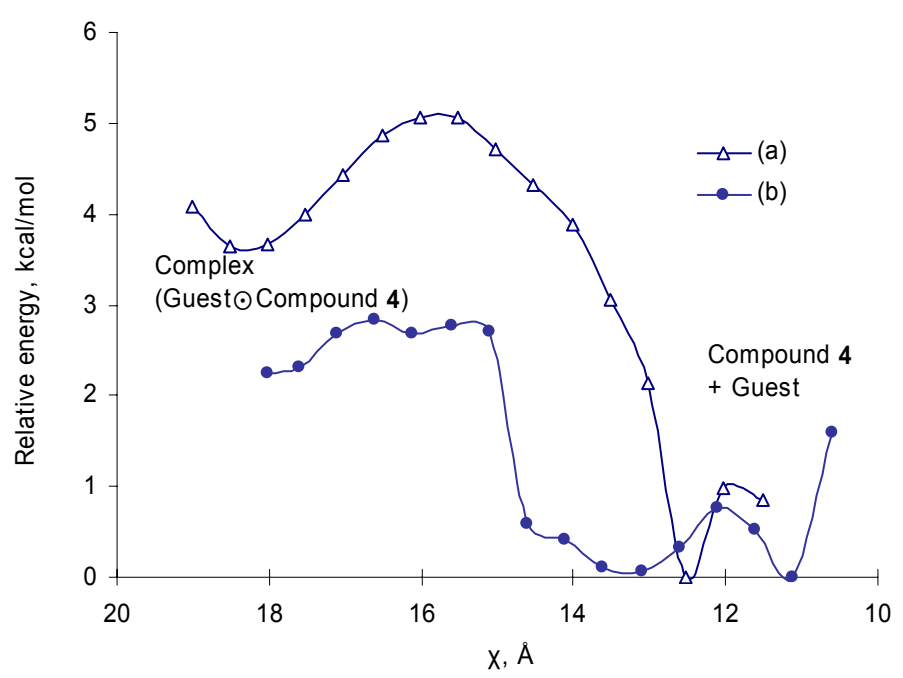

Table S2. Calculated potential energies (DFT, BP86) for complexes 13-17 with ligands residing inside or on the outer side of the basket. 1

\begin{tabular}{lccc}
\hline $\mathrm{CHCl}_{3}$ & -4537.631758 & -4537.633514 & 1.10 \\
\hline pyridine & $\mathrm{E}_{\text {in }}$, hartree & $\mathrm{E}_{\text {out }}$, hartree & $\mathrm{E}_{\text {in }}-\mathrm{E}_{\text {out }}, \mathrm{kcal} / \mathrm{mol}$ \\
azetidine & -3366.762384 & -3366.772944 & 6.63 \\
thiirane & -3291.760337 & -3291.770095 & 6.12 \\
TMA & -3197.168576 & -3197.177556 & 5.64 \\
(trimethylamine) & -3292.98155 & -3292.989628 & 5.07 \\
ethylene & -3595.300413 & -3595.306401 & 3.76 \\
aziridine & -3252.478387 & -3252.482849 & 2.80 \\
imidazole & -3344.730288 & -3344.733648 & 2.11 \\
$\mathrm{CH}_{3} \mathrm{OH}$ & -3234.28218 & -3234.282749 & 0.36 \\
\hline
\end{tabular}




\section{X-Ray Solid-State Structure of 7}

Figure S22. ORTEP representation of the solid-state structure of $\left[7 \cdot \mathrm{CH}_{3} \mathrm{COCH}_{3}\right]$, and ChemDraw structure of 7.

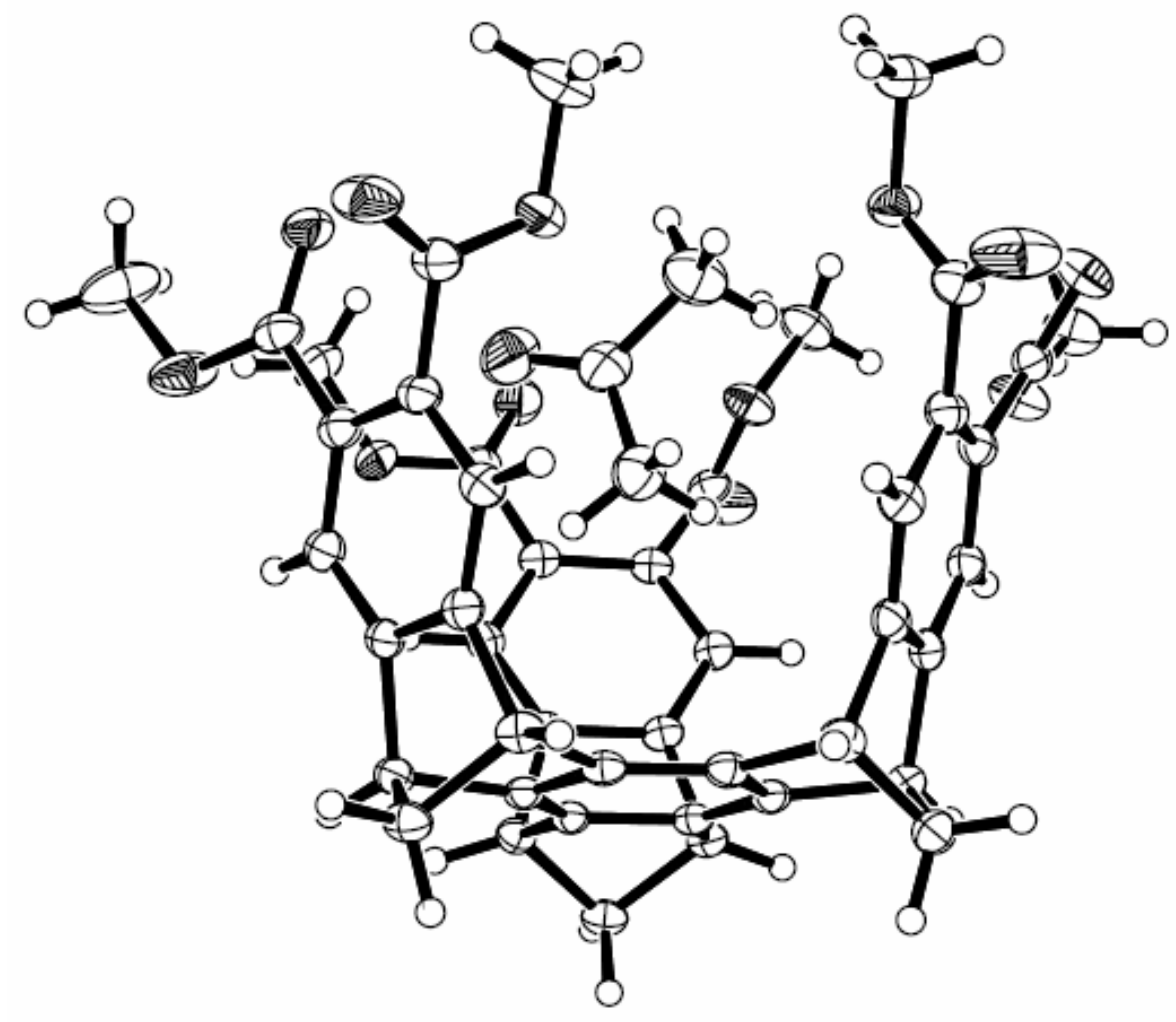

Molecular formula: $\mathrm{C}_{45} \mathrm{H}_{36} \mathrm{O}_{12}+\mathrm{C}_{3} \mathrm{H}_{6} \mathrm{O}_{1}$ (acetone), $\mathrm{M}_{\mathrm{r}}=826.82$, colorless chunk, $0.27 \times 0.27 \times 0.35$ $\mathrm{mm}^{-1}$, triclinic, $\mathrm{P} \overline{1}, \mathrm{a}=11.024(1) \AA \hat{\AA}, \mathrm{b}=11.954(1) \hat{A}, \mathrm{c}=16.548(2) \hat{\AA}, \alpha=94.686(4)^{\circ}, \quad \beta=100.575(4)^{\circ}$, $\gamma=102.183(4)^{\circ}, \mathrm{Vol}=2078.9(4) \AA^{3}, Z=2, \rho_{\text {calcd }}=1.321 \mathrm{gm} / \mathrm{cm}^{3}, \mu=0.096 \mathrm{~mm}^{-1}$, MoKa radiation $(\lambda=$ $0.71073 \AA$ ) $), 150 \mathrm{~K}, 2 \theta_{\max }=55^{\circ}, 56670$ measured reflections, 9515 independent reflections with $\mathrm{R}_{\text {int }}=0.041$, $\mathrm{R} 1$ (on $\left.\mathrm{I}>2 \sigma(\mathrm{I})\right)=0.043$, $\mathrm{wR} 2$ (on all data) $=0.114$, residual electron density (maximum and minimum peaks) 0.395 and $-0.358 \mathrm{e} / \AA^{3}$. Structure was solved by direct methods in SHELXS-97. Full matrix least-squares refinements were done on $\mathrm{F}^{2}$ in SHELXL-97 as incorporated in the WinGX package. The structure has been deposited at the Cambridge Database with reference code number CCDC 636894.<smiles>COC(=O)c1cc2c(cc1C(=O)OC)C1CCC2c2c3c(c4c(c21)C1c2cc(C(=O)OC)c(C(=O)OC)cc2C4c2cc(C(=O)OC)c(C(=O)OC)cc21)C1CC3c2cc(C(=O)OC)c(C(=O)OC)cc21</smiles> 
Figure S23. The ${ }^{1} \mathrm{H}$ NMR spectra of $2.2 \mathrm{mM}$ solution of $4\left(500 \mathrm{MHz}, \mathrm{CDCl}_{3} / \mathrm{CD}_{3} \mathrm{OD}=1: 1\right.$, $300 \mathrm{~K})$.

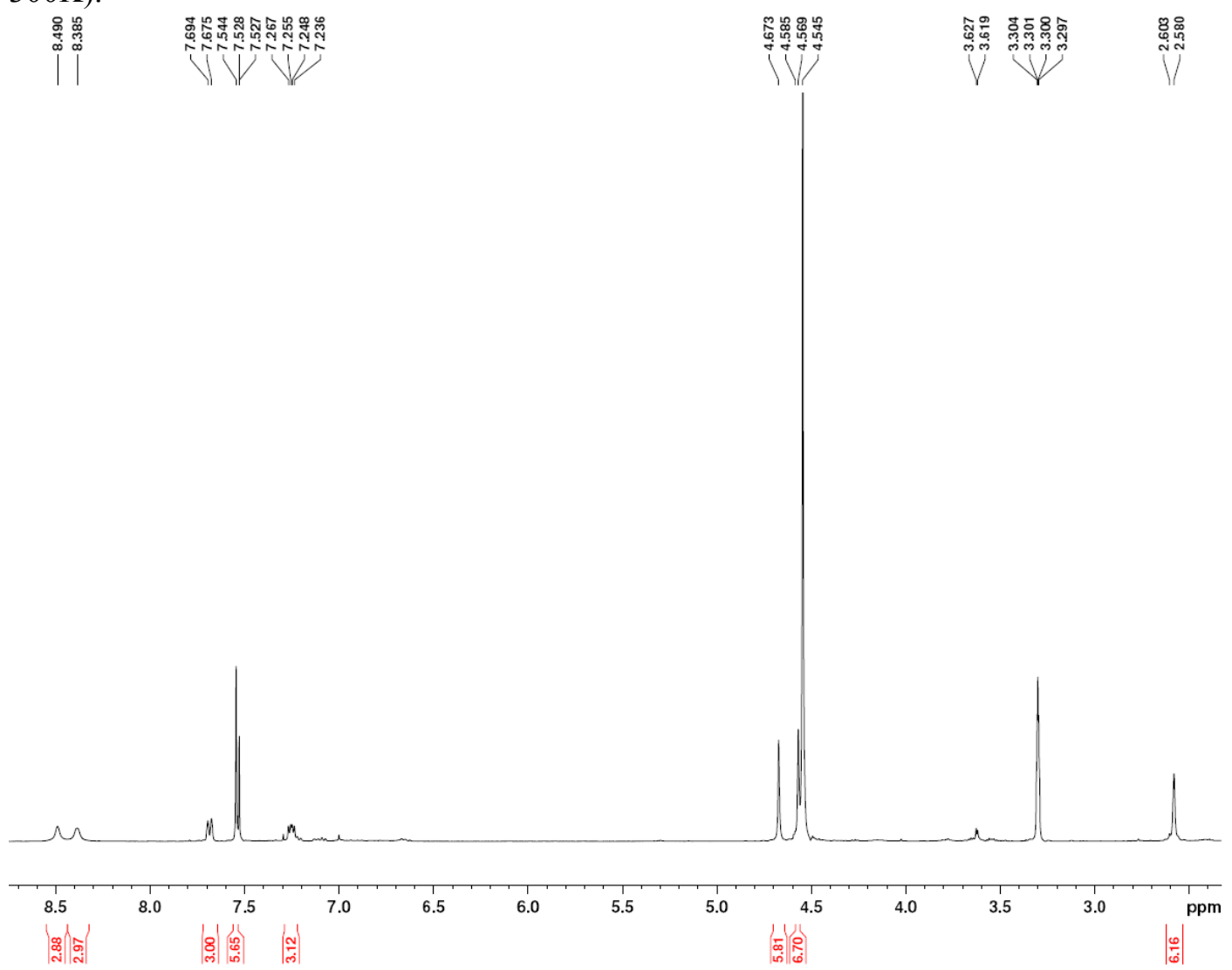

Figure S24. The ${ }^{13} \mathrm{C}$ NMR spectra of $1.0 \mathrm{mM}$ solution of $4\left(500 \mathrm{MHz}, \mathrm{CDCl}_{3}, 300 \mathrm{~K}\right)$.

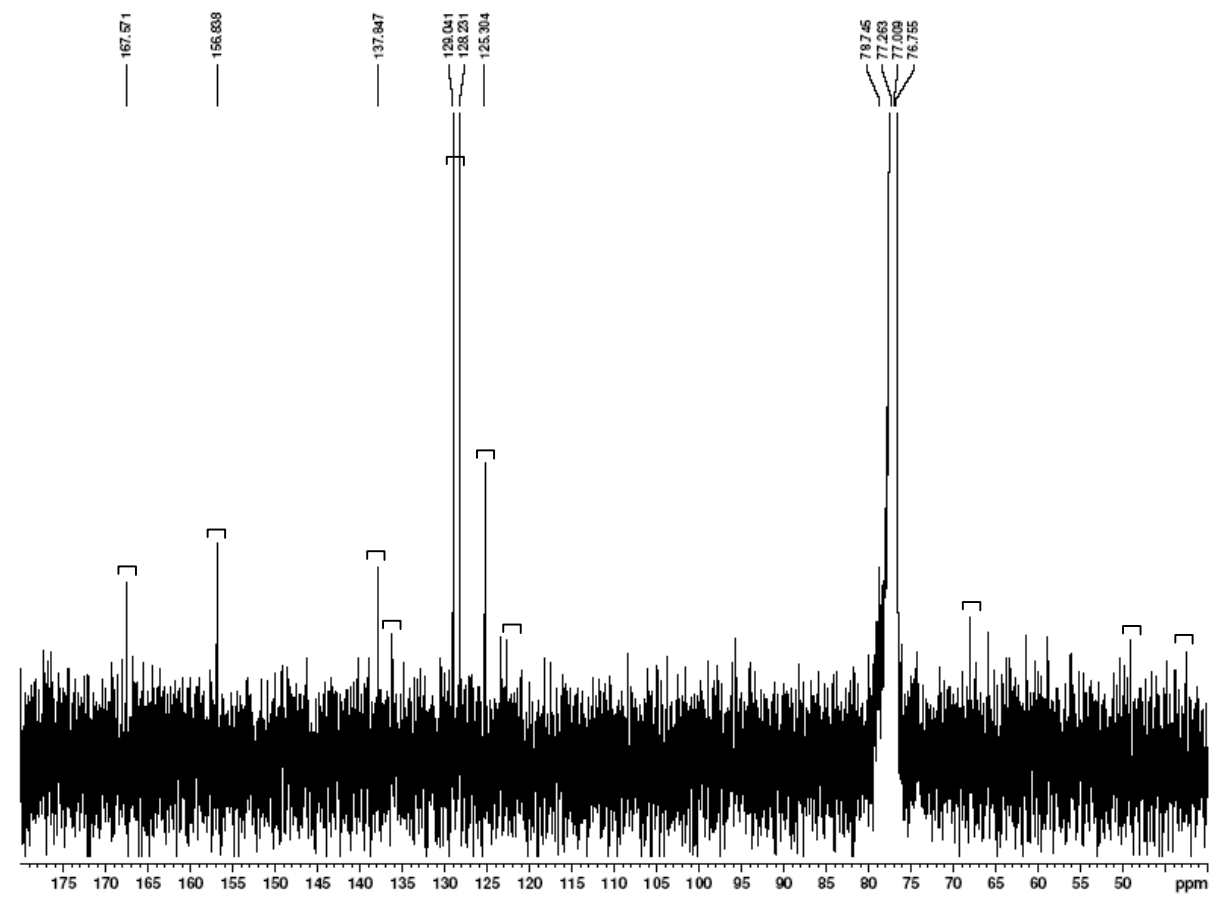


Figure S25. The ${ }^{1} \mathrm{H}$ NMR spectra of $1.1 \mathrm{mM}$ solution of $6\left(500 \mathrm{MHz}, \mathrm{CDCl}_{3} / \mathrm{CD}_{3} \mathrm{OD}=1: 1\right.$, $300 \mathrm{~K}$ ).

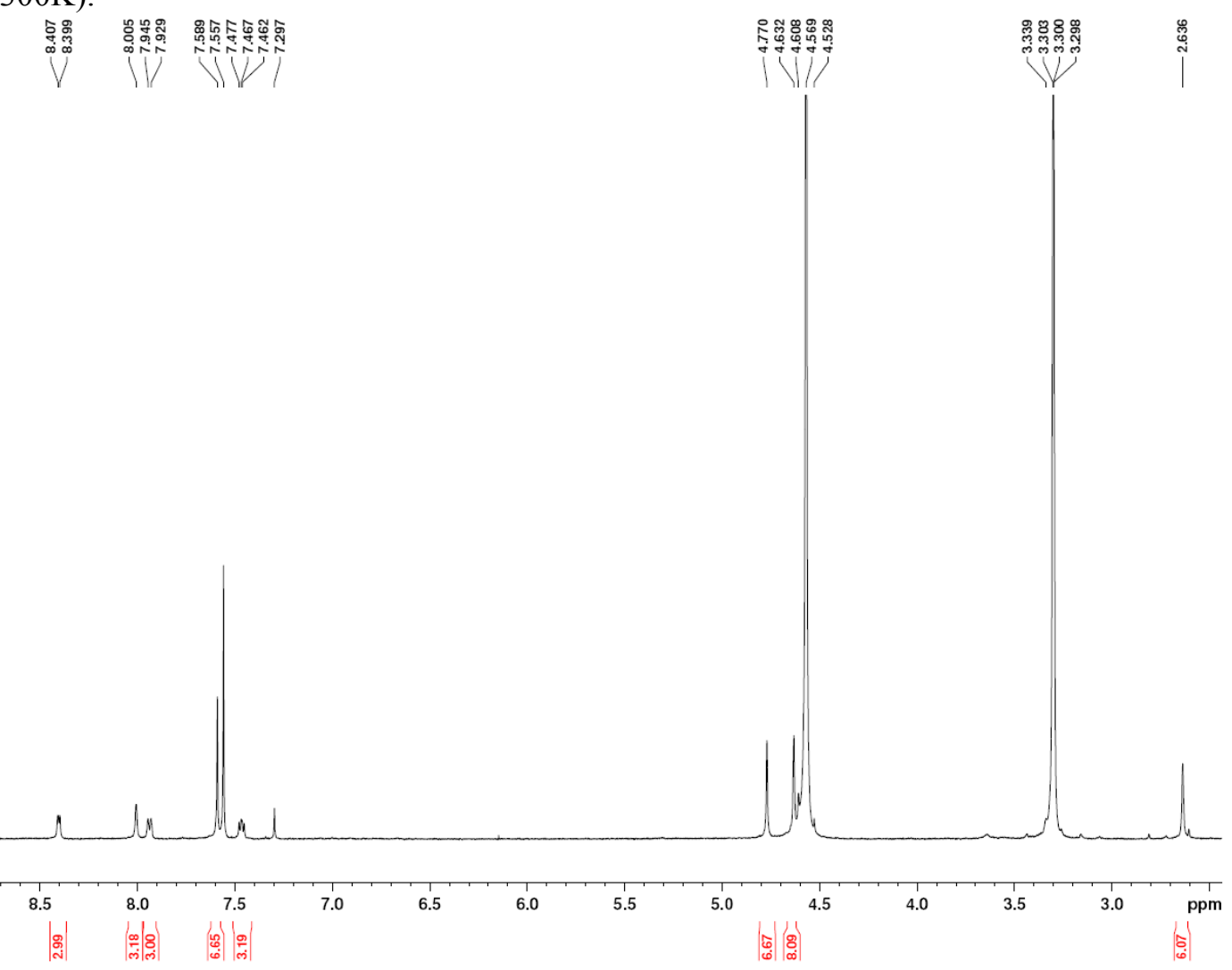

Figure S26. The ${ }^{13} \mathrm{C}$ NMR spectra of $1.1 \mathrm{mM}$ solution of $6\left(500 \mathrm{MHz}, \mathrm{CDCl}_{3} / \mathrm{CD}_{3} \mathrm{OD}=1: 1\right.$, $300 \mathrm{~K}$ ).

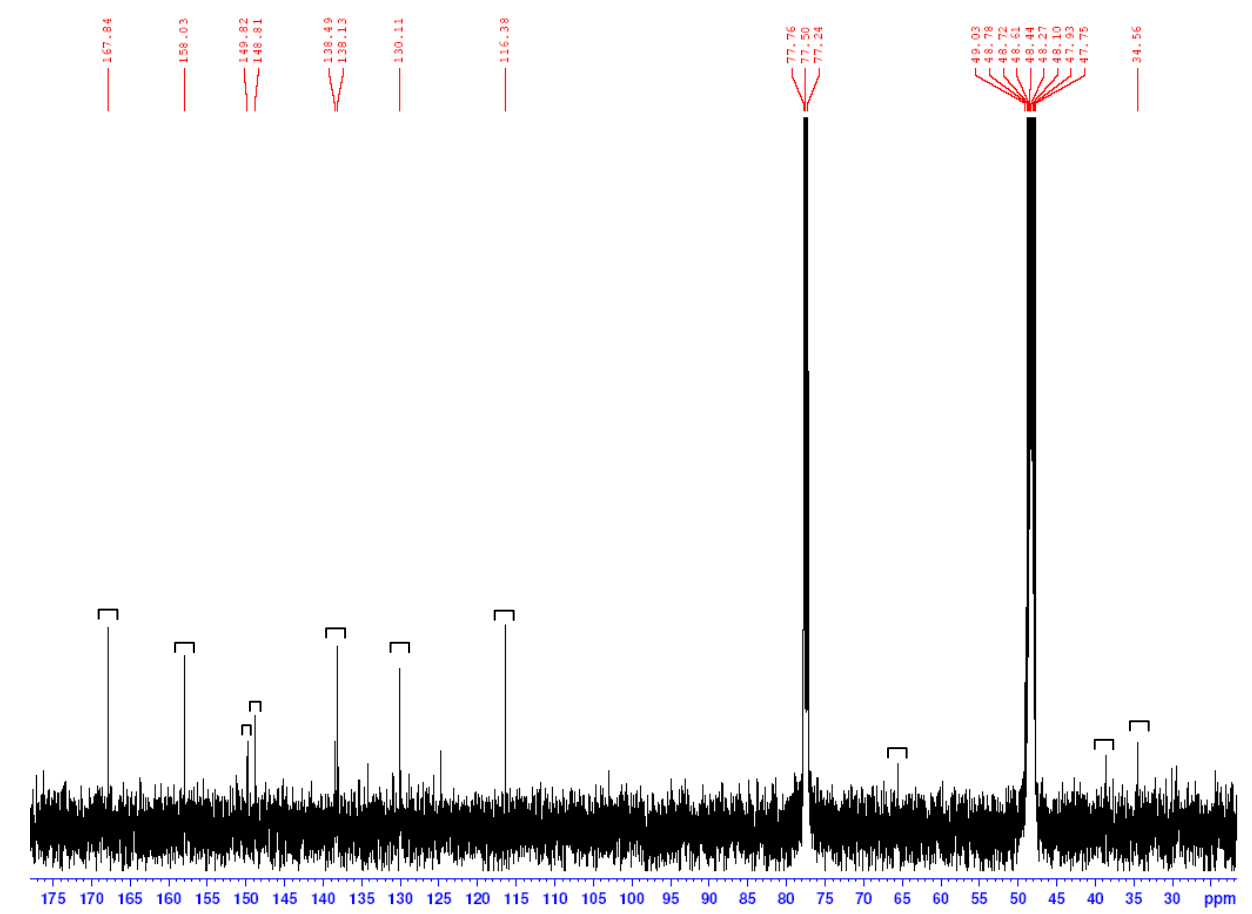




\section{References}

1. Wilcox, C. S. Design, Synthesis, and Evaluation of an Efficacious Function Group Dyad. Methods and Limitations in the Use of NMR for Measuring Host-Guest Interactions. In Frontiers in supramolecular organic chemistry and photochemistry; Wiley-VCH 1991, p. 123-143.

2. Hydrodynamic radius was caculated by Stokes-Einstein equation: $D=\frac{k_{B} T}{6 \pi \eta r_{H}}$, where $\eta$ was obtained from Grunberg equation: $\ln \eta=X_{1} \ln \eta_{1}+X_{2} \ln \eta_{2}$

3. Eichkorn, K.; Treutler, O.; Öhm, H.; Häser, M.; Ahlrichs, R. Chem. Phys. Lett. 1995, 240,283

4. Eichkorn, K.; Weigend, F.; Treutler, O.; Ahlrichs, R. Theor. Chem. Acc. 1997, 97, 119.

5. Becke, A. D. Phys. Rev. A 1988, 38, 3098.

6. Perdew, J. P. Phys. Rev. B 1986, 33, 8822.

7. Schäfer, A.; Horn, H.; Ahlrichs, R. J. Chem. Phys. 1992, 97, 2571.

8. Ahlrichs, R.; Bär, M.; Häser, M.; Horn, H.; Kolmel, C. Chem. Phys. Lett. 1989, 162, 165.

9. Häser, M.; Ahlrichs, R. J. Comput. Chem. 1989, 10, 104.

10. Von Arnim, M.; Ahlrichs, R. J. Comput. Chem. 1998, 19, 1746.

11. Deglmann, P.; Furche, F.; Ahlrichs, R. Chem. Phys. Lett. 2002, 362, 511.

12. The Turbomole basis set library is available via ftp from $\mathrm{ftp} / / / \mathrm{ftp}$. chemie.uni-karlsruhe.de/pub/basen.

13. Gaussian 03, Revision B.03, M. J. Frisch, G. W. Trucks, H. B. Schlegel, G. E. Scuseria, M. A. Robb, J. R. Cheeseman, J. A. Montgomery, Jr., T. Vreven, K. N. Kudin, J. C. Burant, J. M. Millam, S. S. Iyengar, J. Tomasi, V. Barone, B. Mennucci, M. Cossi, G. Scalmani, N. Rega, G. A. Petersson, H. Nakatsuji, M. Hada, M. Ehara, K. Toyota, R. Fukuda, J. Hasegawa, M. Ishida, T. Nakajima, Y. Honda, O. Kitao, H. Nakai, M. Klene, X. Li, J. E. Knox, H. P. Hratchian, J. B. Cross, C. Adamo, J. Jaramillo, R. Gomperts, R. E. Stratmann, O. Yazyev, A. J. Austin, R. Cammi, C. Pomelli, J. W. Ochterski, P. Y. Ayala, K. Morokuma, G. A. Voth, P. Salvador, J. J. Dannenberg, V. G. Zakrzewski, S. Dapprich, A. D. Daniels, M. C. Strain, O. Farkas, D. K. Malick, A. D. Rabuck, K. Raghavachari, J. B. Foresman, J. V. Ortiz, Q. Cui, A. G. Baboul, S. Clifford, J. Cioslowski, B. B. Stefanov, G. Liu, A. Liashenko, P. Piskorz, I. Komaromi, R. L. Martin, D. J. Fox, T. Keith, M. A. Al-Laham, C. Y. Peng, A. Nanayakkara, M. Challacombe, P. M. W. Gill, B. Johnson, W. Chen, M. W. Wong, C. Gonzalez, and J. A. Pople, Gaussian, Inc., Pittsburgh PA, 2003. 